\title{
Impacts of the July 2012 Siberian fire plume on air quality in the Pacific Northwest
}

\author{
Andrew D. Teakles ${ }^{1}$, Rita $\mathrm{So}^{2}$, Bruce Ainslie ${ }^{2}$, Robert Nissen ${ }^{2}$, Corinne Schiller $^{2}$, Roxanne Vingarzan $^{2}$, \\ Ian McKendry ${ }^{3}$, Anne Marie Macdonald ${ }^{4}$, Daniel A. Jaffe ${ }^{5,6}$, Allan K. Bertram ${ }^{7}$, Kevin B. Strawbridge ${ }^{4}$, \\ W. Richard Leaitch ${ }^{4}$, Sarah Hanna ${ }^{7}$, Desiree Toom ${ }^{4}$, Jonathan Baik ${ }^{2}$, and Lin Huang ${ }^{4}$ \\ ${ }^{1}$ Meteorological Service of Canada, Environment and Climate Change Canada, Dartmouth, NS, Canada \\ ${ }^{2}$ Meteorological Service of Canada, Environment and Climate Change Canada, Vancouver, BC, Canada \\ ${ }^{3}$ Department of Geography, University of British Columbia, Vancouver, BC, Canada \\ ${ }^{4}$ Science and Technology Branch, Environment and Climate Change Canada, Toronto, ON, Canada \\ ${ }^{5}$ School of Science, Technology, Engineering, and Mathematics, University of Washington Bothell, Bothell, WA, USA \\ ${ }^{6}$ Department of Atmospheric Sciences, University of Washington, Seattle, WA, USA \\ ${ }^{7}$ Department of Chemistry, University of British Columbia, BC, Canada
}

Correspondence to: Andrew D. Teakles (andrew.teakles@canada.ca)

Received: 6 April 2016 - Discussion started: 1 August 2016

Revised: 15 December 2016 - Accepted: 22 January 2017 - Published: 21 February 2017

\begin{abstract}
Biomass burning emissions emit a significant amount of trace gases and aerosols and can affect atmospheric chemistry and radiative forcing for hundreds or thousands of kilometres downwind. They can also contribute to exceedances of air quality standards and have negative impacts on human health. We present a case study of an intense wildfire plume from Siberia that affected the air quality across the Pacific Northwest on 6-10 July 2012. Using satellite measurements (MODIS True Colour RGB imagery and MODIS AOD), we track the wildfire smoke plume from its origin in Siberia to the Pacific Northwest where subsidence ahead of a subtropical Pacific High made the plume settle over the region. The normalized enhancement ratios of $\mathrm{O}_{3}$ and $\mathrm{PM}_{1}$ relative to $\mathrm{CO}$ of 0.26 and 0.08 are consistent with a plume aged 6-10 days. The aerosol mass in the plume was mainly submicron in diameter $\left(\mathrm{PM}_{1} / \mathrm{PM}_{2.5}=0.96\right)$ and the part of the plume sampled at the Whistler High Elevation Monitoring Site (2182 ma.s.l.) was $88 \%$ organic material. Stable atmospheric conditions along the coast limited the initial entrainment of the plume and caused local anthropogenic emissions to build up. A synthesis of air quality from the regional surface monitoring networks describes changes in ambient $\mathrm{O}_{3}$ and $\mathrm{PM}_{2.5}$ during the event and contrasts them to baseline air quality estimates from the AURAMS chemical transport model without wildfire emissions. Overall, the
\end{abstract}

smoke plume contributed significantly to the exceedances in $\mathrm{O}_{3}$ and $\mathrm{PM}_{2.5}$ air quality standards and objectives that occurred at several communities in the region during the event. Peak enhancements in $8 \mathrm{~h} \mathrm{O}_{3}$ of 34-44 ppbv and $24 \mathrm{~h} \mathrm{PM}_{2.5}$ of $10-32 \mu \mathrm{g} \mathrm{m}^{-3}$ were attributed to the effects of the smoke plume across the Interior of British Columbia and at the Whistler Peak High Elevation Site. Lesser enhancements of 10-12 ppbv for $8 \mathrm{~h} \mathrm{O}_{3}$ and of $4-9 \mu \mathrm{g} \mathrm{m}^{-3}$ for $24 \mathrm{~h} \mathrm{PM}_{2.5}$ occurred across coastal British Columbia and Washington State. The findings suggest that the large air quality impacts seen during this event were a combination of the efficient transport of the plume across the Pacific, favourable entrainment conditions across the $\mathrm{BC}$ interior, and the large scale of the Siberian wildfire emissions. A warming climate increases the risk of increased wildfire activity and events of this scale reoccurring under appropriate meteorological conditions.

\section{Introduction}

Wildfires emit significant amounts of primary pollutants including fine particulate matter $\left(\mathrm{PM}_{2.5}\right)$, carbon monoxide $(\mathrm{CO})$, nitrogen oxides $\left(\mathrm{NO}_{x}\right)$, and non-methane organic carbons (NMOCs). These pollutants can react to form ozone $\left(\mathrm{O}_{3}\right)$ and secondary organic aerosols (SOA), which 
can affect downwind air quality and climate over a wide range of scales from local (Akagi et al., 2011, 2012, 2013; Smolyakov et al., 2014), to regional (Wigder et al., 2013), to intercontinental (Jaffe et al., 2001, 2004; Bertschi et al., 2004; Bertschi and Jaffe, 2005; Lapina et al., 2006; Pfister et al., 2006; Weiss-Penzias et al., 2007; Bein et al., 2008; Strada et al., 2012; Jaffe and Wigder, 2012). Short-term exposures to air pollution from biomass burning have been found to be associated with a range of health impacts, including respiratory symptoms, increased hospital admissions, and emergency room visits and premature mortality (Henderson and Johnston, 2012).

The rate of $\mathrm{O}_{3}$ and SOA formation in wildfire plumes, and hence the potential for adverse air quality and health impacts, can vary considerably due to several factors, including biomass fuel type, combustion characteristics, atmospheric conditions, and downwind distance (Akagi et al., 2011; Jaffe and Wigder, 2012). The $\mathrm{O}_{3}$ production in biomass burning is driven by photochemical reactions of $\mathrm{NO}_{x}$ and nonmethane organic carbons (NMOCs) and typically occurs in a $\mathrm{NO}_{x}$ limited environment. $\mathrm{O}_{3}$ enhancement relative to $\mathrm{CO}$, also known as the normalized enhancement ratio (NER; $\Delta \mathrm{O}_{3} / \Delta \mathrm{CO}$ ), for temperate and boreal wildfires generally increasew as the plume ages and is typically in the range of 0.1 to 0.7 (Jaffe and Wigder, 2012). A similar trend is present for the NER of $\mathrm{PM}_{1}\left(\Delta \mathrm{PM}_{1} / \Delta \mathrm{CO}\right)$ for plumes aged $<2$ days; yet for older plumes, SOA formation can be overshadowed by PM loss due to wet and dry deposition, cloud processing, and/or evaporation (Wigder et al., 2013). Further study is still required to better understand the interactions of the above factors on downwind air quality for long-range transport (LRT) events.

The Russian boreal forests represent the largest forested region on Earth with an aerial coverage of approximately 8 million $\mathrm{km}^{2}$ (Stocks, 2004). About $1 \%$ of this region is damaged from 10000 to 35000 forest fires annually (Isaev et al., 2002). Jaffe et al. (2004) estimated that the active Siberian wildfire season in 2003 caused summertime $\mathrm{O}_{3}$ enhancements of 9-17 ppbv, which led to episodic $\mathrm{O}_{3}$ exceedances in western North America. Other studies have also demonstrated the LRT of wildfire smoke from Siberia can affect air quality over Asia (Jeong et al., 2008; Jung et al., 2016) and contribute to arctic haze (Brock et al., 2011).

This study examines an episodic LRT event of Siberian wildfire smoke to the Pacific Northwest that had significant and widespread air quality impacts on 6-10 July 2012. Record temperatures and dry weather across Siberia in 2012 led to increased wildfire activity. Over 17000 wildfires were detected in July and August 2012 alone. The Fire Inventory from NCAR model (FINN; Wiedinmyer et al., 2011) estimated that $48 \mathrm{Tg}$ of CO emissions occurred by August 2012, which was already more than double the biomass burning emission for the entire 2010 season and second only to the $72 \mathrm{Tg}$ from the 2003 season (NASA, 2012).
Cottle et al. (2014) examined the impact of this event in the Lower Fraser Valley (LFV) in British Columbia, Canada, using lidar measurements taken at the University of British Columbia. HYSPLIT (Hybrid Single-Particle Lagrangian Integrated Trajectory) trajectory analysis confirmed that aerosol layers subsiding over the LFV had largely originated from over wildfire source areas in Siberia at least 6 days earlier. Aerosol backscatter measurement and low depolarization volume ratios during the event showed the progressive entrainment of smoke into the LFV through 10 July 2012, which coincided with the high $\mathrm{PM}_{2.5}$ observed by the region's fixed air quality monitoring network. This study expands on the Cottle et al. (2014) work in a number of significant ways: it analyzes potential air quality impacts over a much greater geographical area encompassing large parts of British Columbia and Washington State (WA), uses detailed air quality measurements at a high elevation background site to provide insight into plume chemistry, and makes use of photochemical modelling to establish baseline air quality conditions in the absence of any wildfire emissions to determine the smoke plume's contribution to degraded air quality and exceedances of regional air quality objectives and national standards of $\mathrm{O}_{3}$ and $\mathrm{PM}_{2.5}$.

\section{Methods}

\subsection{Monitoring data}

\subsubsection{Ambient air quality monitoring data}

Ambient $\mathrm{O}_{3}$ and $\mathrm{PM}_{2.5}$ data were obtained from several air quality monitoring networks (Fig. 1c and d), including 35 stations from the British Columbia Ministry of Environment (BCMoE) network (BCMoE, 2014a), 22 air quality monitors within the LFV Air Quality Monitoring Network (Metro Vancouver, 2014), and 15 stations from the Washington State Monitoring Network (WSMN) (WA ECY, 2012). The air quality monitoring network across British Columbia is, in part, co-managed by the National Air Pollution Surveillance Network (NAPS) (Dabek-Zlotorzynska et al., 2011). Study sites also included two marine background sites Amphitrite Point, Ucluelet (site C, 18 m a.s.l., on Vancouver Island; McKendry et al., 2014), and Cheeka Peak (site D, $480 \mathrm{~m}$ a.s.l., in WA; Weiss-Penzias et al., 2004) - and two elevated background sites - Whistler Peak (site 1, $2182 \mathrm{~m}$ a.s.l., located $120 \mathrm{~km}$ north of Vancouver; Takahama et al., 2011; Macdonald et al., 2011) and Mt. Rainier Jackson Visitor Centre (site F, 1782 m a.s.l., located in Pierce County, WA). A description of the data analyzed and sampling methodologies for the various networks and sampling sites is summarized in Table 1. 


\subsubsection{Lidar sites}

Two lidars were used in this study: one located on the University of British Columbia Point Grey campus in Vancouver (site B, $80 \mathrm{~m}$ a.s.l.) and a second located at the north end of Whistler village (site A, $650 \mathrm{~m}$ a.s.1.), approximately $8 \mathrm{~km}$ north of the Whistler Peak High Elevation Site (WHI) (Gallagher et al., 2012; Strawbridge, 2013). The lidars use a Continuum Inlite III laser with an approximate output power of $1.5 \mathrm{~W}$ at $10 \mathrm{~Hz}$ and operates simultaneously at wavelengths of 532 and $1064 \mathrm{~nm}$. The system measures the return signals through three detection channels: one at $1064 \mathrm{~nm}$ and two at $532 \mathrm{~nm}$ (one for each polarization). Backscatter information provided by the upward pointing setup has a vertical resolution of $3 \mathrm{~m}$ from near the ground up to $15 \mathrm{~km}$ and uses a $10 \mathrm{~s}$ averaging period. Additional details on the lidar systems can be found in Strawbridge (2013).

\subsubsection{Whistler Peak High Elevation Site}

Air quality measurements were collected at the Whistler Peak High Elevation Site (see Table 1 for details). CO was measured with Thermo Environmental Instruments Inc. Model 48C Trace Level analyzer and $\mathrm{O}_{3}$ was measured with a Thermo Environmental Instruments Inc. UV absorption monitor (TECO 49C). Particle chemistry was provided both through integrated filter samples and continuously with an Aerosol Chemical Speciation Monitor (ACSM). Inorganic ions $\left(\mathrm{Cl}^{-}, \mathrm{NO}_{3}^{-}, \mathrm{Na}^{+}, \mathrm{NH}_{4}^{+}, \mathrm{K}^{+}, \mathrm{Mg}^{2+}\right.$, and $\left.\mathrm{Ca}^{2+}\right)$ were analyzed on $48 \mathrm{~h}$ filter samples by ion chromatography (IC) and ICP-MS. OC, POC, and EC measurements were also obtain on a Sunset Lab OC-EC aerosol analyzer (Sunset Laboratory Inc., 2016) using the EnCan Total-900 thermal method (Huang et al., 2006) with an 8-day sampling period (3-11 July) split between day and night. The ACSM provided particle chemical composition for $\mathrm{SO}_{4}^{2-}, \mathrm{NO}_{3}^{-}, \mathrm{Cl}^{-}, \mathrm{NH}_{4}^{+}$, and organics on a $30 \mathrm{~min}$ time resolution. Optical measurements of black carbon (rBC) were acquired using the Single Particle Soot Photometer (SP2). During the study, the SP2 instrument had a steady $6 \%$ loss in its laser power; however, internal diagnostics suggest that the power loss is unlikely to significantly affect the readings because heating aerosol during intake was unaffected. SP2 readings were also affected by a leak in the inlet plumbing noticed after the event. Particle size distributions were measured by an optical particle counter (OPC) over the $(0.25$ to $32 \mu \mathrm{m})$ for the entire period and also from a scanning mobility particle sizer (SMPS) (14$572 \mathrm{~nm}$ diameter) from 9 July onwards. Details of the trace gas and particle measurements at Whistler Peak are discussed by Macdonald et al. (2011) and Takahama et al. (2011).

\subsection{Trajectory and dispersion modelling}

A detailed analysis by Cottle et al. (2014) using HYSPLIT trajectories and high-resolution smoke dispersion models generated with the Bluesky framework (Sullivan et al., 2008) concluded that wildfire sources within North America did not significantly influence air quality within the LFV during the 6-10 July 2012 period.

A similar analysis was done using the CMC trajectory model (D'Amours et al., 2015) with meteorological fields from the Global Environmental Multiscale Limited-Area Model (GEM-LAM) $15 \mathrm{~km}$ model at $15 \mathrm{~min}$ intervals for nearby North America wildfires (Long Draw, Oregon, and Waldo Canyon, Colorado). Forward trajectories were integrated for a $72 \mathrm{~h}$ period at release heights of 10,100 , and $1000 \mathrm{~m}$ above ground level (a.g.l.). Figure S1 in the Supplement shows the forward trajectories for the Long Draw and Waldo Canyon wildfires released at 00:00 UTC on 9 July 2012 and confirmed that smoke from these sources were unlikely to have contributed to the degraded ambient air quality observed over the larger geographical extent in this study. Trajectory modelling was not done for the few small wildfires within the Interior of British Columbia. Overall, the effects of these sources are expected to be localized and with only minor air quality enhancements until after 9 July 2012.

\subsection{Analysis of $\mathrm{O}_{3}$ and $\mathrm{PM}_{2.5}$ impacts}

Based on measurements collected at over 70 air quality monitoring stations in the Pacific Northwest, the air quality impacts of the Siberian wildfire plume were assessed by examining the $\mathrm{O}_{3}$ and $\mathrm{PM}_{2.5}$ concentrations at various averaging periods of 1,8 , and $24 \mathrm{~h}$, depending on the pollutant. For each monitoring station, severe air quality episodes were identified using the regional objective and national standards, applicable at the time of the event (Table 2), as thresholds and were compared to the average historical July daily maxima values from 2000 to 2010. It should be noted that although some of these standards, for example the Canada Wide Standard (CWS) for $\mathrm{O}_{3}$ (CCME, 2014), are based on multi-year statistics, all standards were compared to hourly observations of their respective averaging periods.

To further characterize the timing and spatial extent of these impacts, baseline concentrations of $\mathrm{O}_{3}$ and $\mathrm{PM}_{2.5}$ over the Pacific Northwest, in the absence of any wildfire emissions from either Siberia or from within North America, were simulated using the AURAMS (A Unified Regional Air-quality Modelling System) air quality transport model (Gong et al., 2006, with updates from Kelly et al., 2012) and were compared with observations.

\subsubsection{AURAMS baseline simulation}

AURAMS was run over a 12-day period (5-15 July 2012) using a nested configuration of 12 and $4 \mathrm{~km}$ grid spacing with the inner $(4 \mathrm{~km})$ domain covering southern British Columbia and northern WA (Fig. 1a and c). Meteorology for the simulations was provided by Environment and Climate Change Canada's (ECCC) GEM-LAM weather forecast model (Côté 
Table 1. Instrument list for various monitoring networks used in the study.

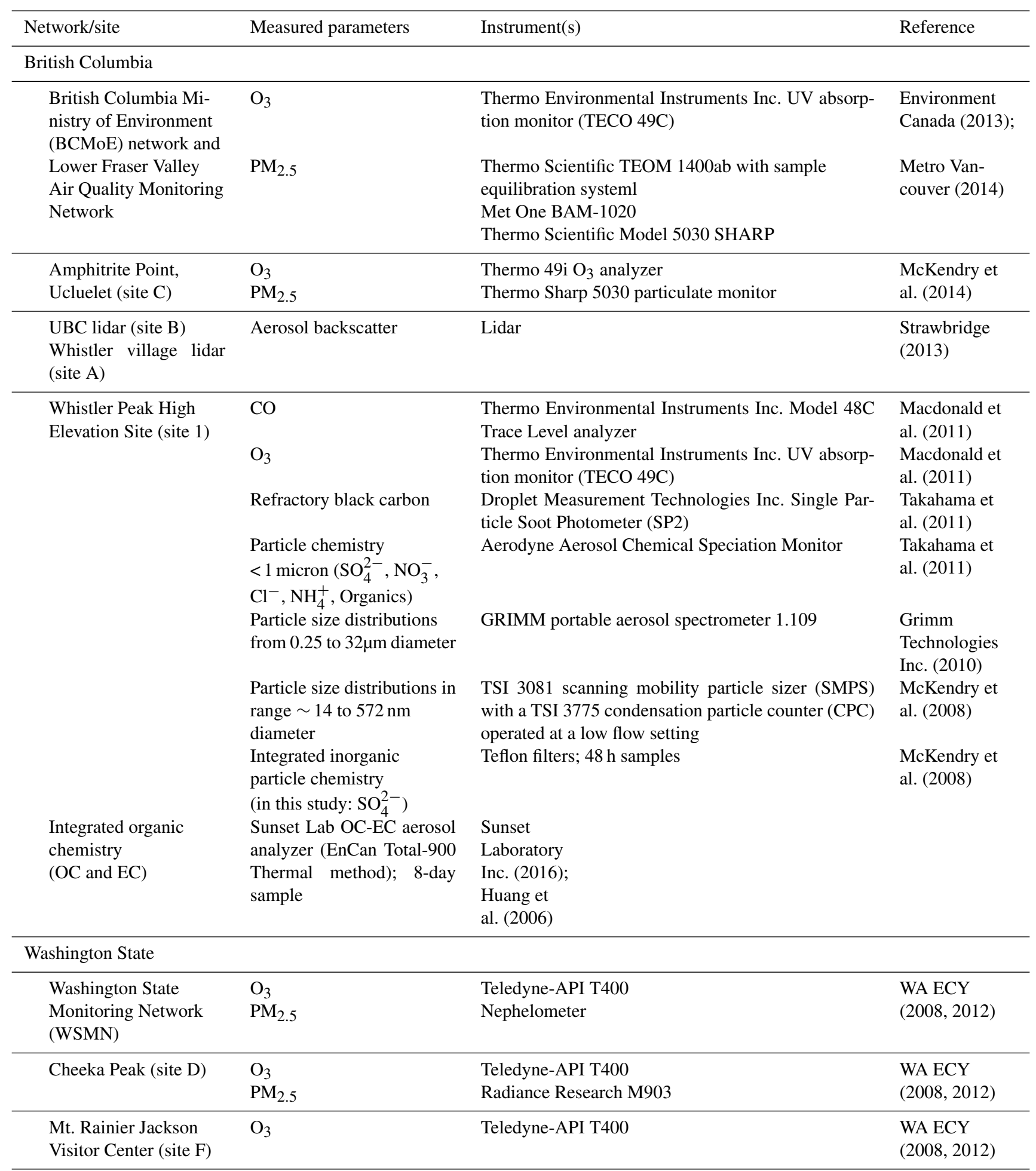



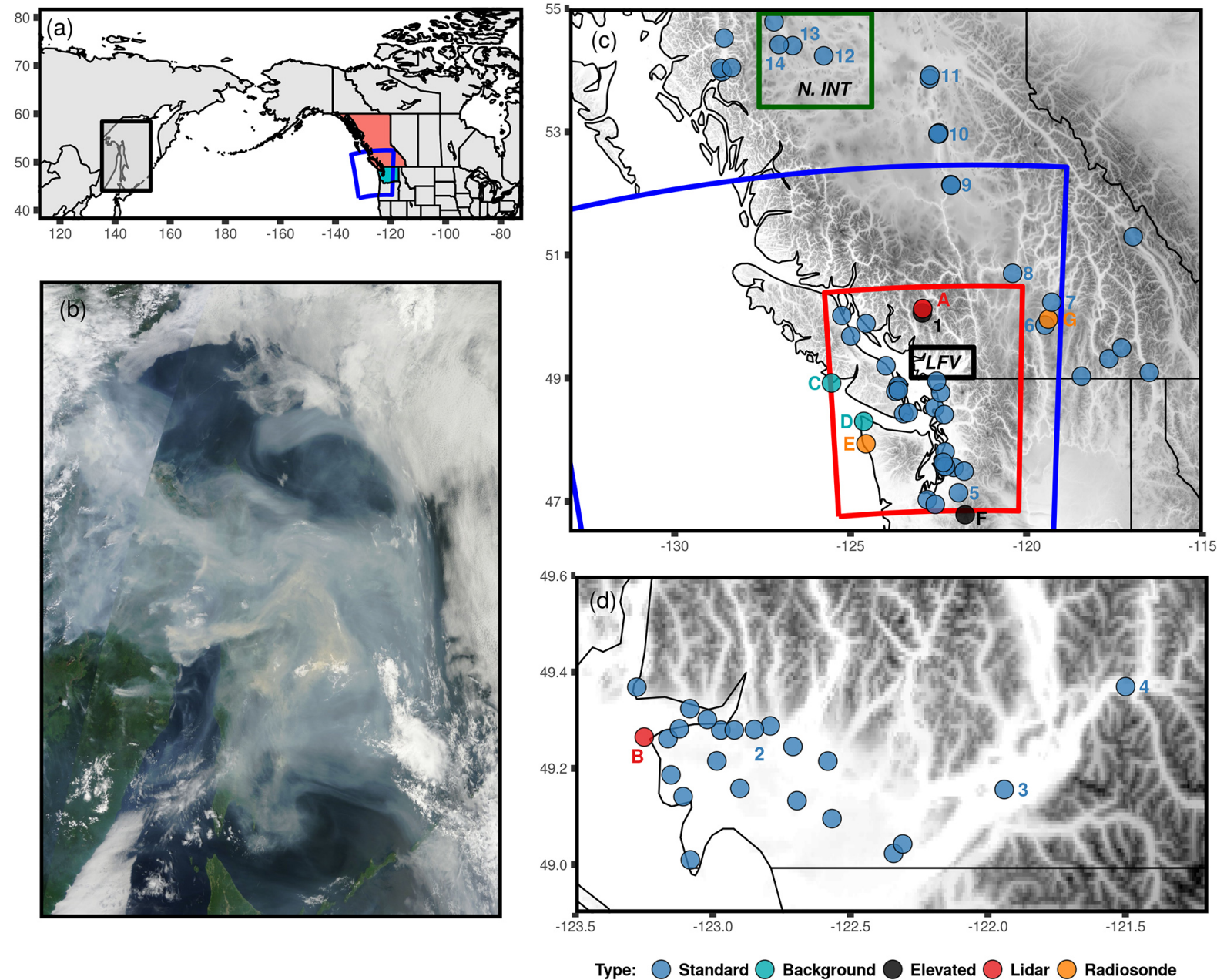

Figure 1. Map of the monitoring network data and AURAMS modelling domain used in the study. The pink and blue regions in (a) highlights the two geographical regions of interest, British Columbia and Washington state, respectively. The black outlined area in (a) highlights the geographical location of the MODIS True Colour image on 29 June 2012 from the NASA earth Observatory site (b). The blue and red outlined areas in either (a) and/or (c) highlight the 12 and $4 \mathrm{~km}$ AURAMS grid domains, respectively. The green outline in (c) highlights the Northern Interior sites that fall outside the gridded domain. The Lower Fraser Valley (LFV; black outline in c) inset (d) displays the Metro Vancouver air quality monitoring network and the location of the UBC lidar. Abbreviations used in this figure are defined in Table S1 and throughout the text. Topography shaded in panels (c) and (d).

Table 2. 2012 Ambient air quality standards and objective for $\mathrm{O}_{3}$ and $\mathrm{PM}_{2.5}$.

\begin{tabular}{lrrrl}
\hline Standard/objective & Pollutant & Averaging period & Value & Reference \\
\hline Canada NAAQS & $\mathrm{O}_{3}$ & $1 \mathrm{~h}$ & $82 \mathrm{ppbv}$ & Health Canada (1999) \\
\hline Canada CWS & $\mathrm{O}_{3}$ & $8 \mathrm{~h}$ & $65 \mathrm{ppbv}$ & CCME (2014) \\
BC provincial and Metro Vancouver & & & $65 \mathrm{ppbv}$ & BCMoE (2014b) \\
Vancouver & & & & Metro Vancouver (2014) \\
US EPA NAAQS & & & $75 \mathrm{ppbv}$ & US EPA (2014) \\
\hline Canada CWS & $\mathrm{PM}_{2.5}$ & $24 \mathrm{~h}$ & $30 \mu \mathrm{g} \mathrm{m}^{-3}$ & CCME (2014) \\
BC provincial and Metro & & & $25 \mu \mathrm{g} \mathrm{m}^{-3}$ & BCMoE (2014b) \\
Vancouver & & & \\
US EPA NAAQS & & $35 \mu \mathrm{g} \mathrm{m}^{-3}$ & US EPA (2014) \\
\hline
\end{tabular}


et al., 1998) run at a $2.5 \mathrm{~km}$ resolution and then interpolated to the AURAMS domains. GEM-LAM was run in a series of $30 \mathrm{~h}$ simulations starting from $00 \mathrm{Z}$ with the first $6 \mathrm{~h}$ of each simulation discarded as "spin up" in order to allow model fields to reach steady state. The model was run with anthropogenic emissions based on the 2010 Canadian and 2008 US emission databases. Emission totals for both databases were adjusted to 2012 levels using Metro Vancouver forecasted and backcasted LFV emission estimates (GVRD, 2007). The model used biogenic emissions that calculated using the Biogenic Emissions Inventory System (BEIS) version 3.0.9 emissions algorithms and Biogenic Emissions Landuse Database 3 (BELD3) data. AURAMS employed the ADOMII gas-phase chemical mechanism (Stockwell et al., 1989) and used a chemically speciated 12-bin sectional distribution to characterize particulate matter from 0.01 to $40.96 \mu \mathrm{m}$ in diameter.

Lateral boundary conditions to the AURAMS model along its outer $(12 \mathrm{~km})$ domain were supplied by seasonally representative climatological values for some species and for $\mathrm{O}_{3}$ an additional adjustment was made to the climatological boundary conditions in response to the local tropopause height (Makar et al., 2010). Lateral boundary conditions to the inner $4 \mathrm{~km}$ domain were supplied from the $12 \mathrm{~km}$ model output. AURAMS runs did not include any wildfire emissions from either Siberia or from within North America.

The reliability of the AURAMS baseline simulation (Table S2) was examined by comparing the $1 \mathrm{~h}$ observed and modelled $\mathrm{O}_{3}$ and $\mathrm{PM}_{2.5}$ during non-event days (5 July and from 12 to 15 July). Within the $4 \mathrm{~km}$ domain, the model bias in $1 \mathrm{~h} \mathrm{O} \mathrm{O}_{3}$ and $\mathrm{PM}_{2.5}$ is relatively low $(2.35 \mathrm{ppbv}$ and $1.14 \mu \mathrm{g} \mathrm{m}^{-3}$, respectively). Over the $12 \mathrm{~km}$ domain, the $\mathrm{O}_{3}$ and $\mathrm{PM}_{2.5}$ performance degraded, with $\mathrm{O}_{3}$ bias and RMSE of $14.3 \mathrm{ppbv}$ and $20.86 \mathrm{ppbv}$, respectively, and $\mathrm{PM}_{2.5}$ bias and RMSE of 5.84 and $10.21 \mathrm{\mu g} \mathrm{m}^{-3}$, respectively. However, it should be noted that the majority of the study sites fall within the $4 \mathrm{~km}$ domain. Overall, the $1 \mathrm{~h}$ model performance of the baseline simulation is comparable to the assessed reliability of the AURAMS model from other studies (Makar et al., 2014).

\subsubsection{LRT enhancements analysis}

LRT enhancements were identified when ambient air quality conditions in the Pacific Northwest departed from the baseline conditions as modelled by AURAMS, beyond a reasonable margin of error. As the model bias can affect the magnitude of the LRT enhancement estimates, the uncertainty in these enhancements was quantified in a conservative manner in this study. This was done by examining the range of differences between the 8 and $24 \mathrm{~h}$ observed and modelled values for $\mathrm{O}_{3}$ and $\mathrm{PM}_{2.5}$, respectively, during non-event days (5 July and from 12 to 15 July) at each monitoring location. Table $\mathrm{S} 1$ in the Supplement provides uncertainty estimates in $8 \mathrm{~h} \mathrm{O}_{3}$ and $24 \mathrm{~h} \mathrm{PM}_{2.5}$ for selected sites. For reporting pur- poses, enhancements for multiple monitoring locations were aggregated, when appropriate, to reflect the average contribution of the Siberian plume across the different regions in the Pacific Northwest.

\section{Results and discussion}

\subsection{July 2012 smoke event overview}

On 29 June 2012, smoke originating from wildfires over eastern Russia, as noted by the NASA Earth Observatory group, drifted eastward across the Sea of Japan, the Sea of Okhotsk, and Kamchatka (Fig. 1b). Moderate Resolution Imaging Spectroradiometer (MODIS) Aerosol Optical Depth (AOD) imagery between 1 and 6 July, shown in Fig. S2a-f, illustrates the progression of the aerosol plume (AOD > 1) across the Pacific to western North America. Long-range transport of aerosols was aided by strong zonal flow established as a developing storm tracked from the Bearing Sea to the Gulf of Alaska. Subsidence ahead of the subtropical Pacific high is thought to have contributed to the descent of the plume over the study area. In western North America, subsidence and mountain wave activity are found to be important factors in bringing mid-tropospheric dust layers in range of boundary layer entrainment process (McKendry et al., 2001; Hacker et al., 2001).

On 7 July, the MODIS True Colour imagery (Fig. 2) shows the smoke plume oriented northeast to southwest across the southern British Columbia and Washington State. At this time, degraded air quality conditions were observed inland over the Interior of British Columbia, where both the $8 \mathrm{~h} \mathrm{O}$ and $24 \mathrm{~h} \mathrm{PM}_{2.5}$ exceedances occurred at Kamloops (site 8). From 8 to 9 July, poor air quality conditions continued to spread across the Interior, coinciding with the northward and inland progression of the plume as collaborated by AOD imagery (Fig. S2g), and caused air quality exceedances at several communities (see Table 3). Over in the coastal region, elevated $\mathrm{O}_{3}$ and $\mathrm{PM}_{2.5}$ also occurred on 8 July, with isolated $8 \mathrm{~h} \mathrm{O}_{3}$ exceedances at Chilliwack (site 3) and Enumclaw (site 5). MODIS AOD on 10 July (Fig. S2h) showed the plume remnant had shifted southeastward and out of the Pacific Northwest domain.

Figure 3 provides an overview of the maximal enhancements to $8 \mathrm{~h} \mathrm{O}_{3}$ and $24 \mathrm{~h} \mathrm{PM}_{2.5}$ estimated based on the differences between the ambient air quality observation and the baseline AURAMS air quality modelling for the event. Overall, the baseline modelling suggests that the greatest air quality impacts from the Siberian wildfire smoke were in the Interior of British Columbia and at the Whistler Peak High Elevation Monitoring Site with peak increases of 34-44 ppbv for $8 \mathrm{~h} \mathrm{O}_{3}$ and $10-32 \mu \mathrm{g} \mathrm{m}^{-3}$ for $24 \mathrm{~h} \mathrm{PM}_{2.5}$. The coastal portions of British Columbia and Washington State saw lesser enhancements of $10-14 \mathrm{ppbv}$ and $4-9 \mu \mathrm{g} \mathrm{m}^{-3}$, respectively (Table 4). The regional disparity in the enhancement may be attributable to difference in subsidence across the region. 

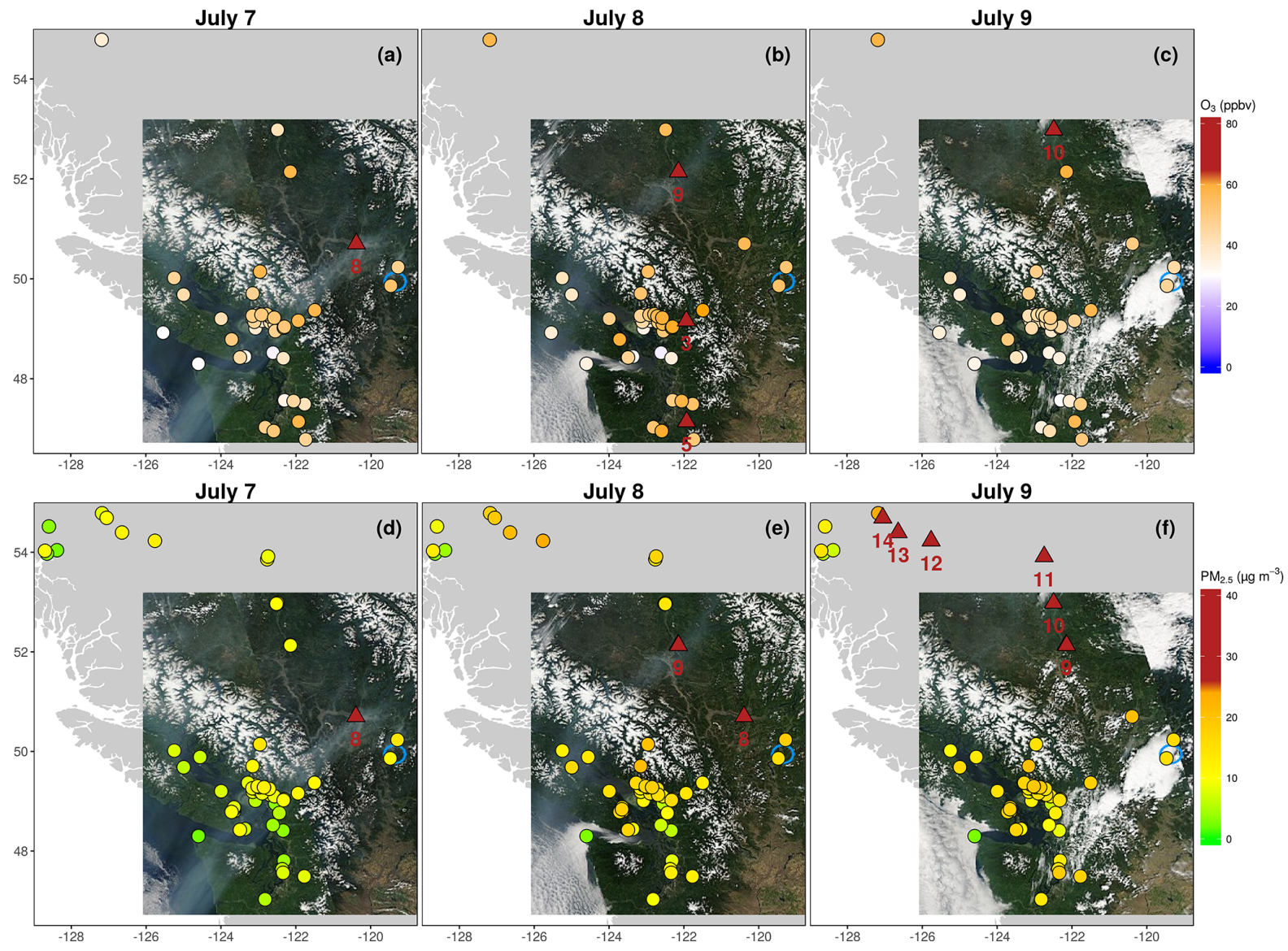

Figure 2. MODIS True Colour image composite maps for 7, 8, and 9 July 2012 overlaid with daily maximum of 8 h $\mathrm{O}_{3}$ (a, b, and c, respectively) and of $24 \mathrm{~h} \mathrm{PM}_{2.5}$ (d, e, f, respectively) for the study sites. The locations where observed concentration exceed the national or regional air quality standards for either $\mathrm{O}_{3}$ or $\mathrm{PM}_{2.5}$ are indicated in red triangles in the appropriate panel and described in Table 3. The light blue circle on the MODIS source imagery indicates the location of the Kelowna Airport (site G) on all panels. Abbreviations used in this figure are defined in Table S1 and throughout the text.

Coastal regions had stable atmospheric conditions, leading to stagnant conditions under a strong thermal inversion between 500 and $1000 \mathrm{~m}$ a.s.l. (Fig. 4a). Stable atmospheric conditions likely limited the entrainment of the plume over the coastal area and caused a buildup of local anthropogenic emissions. Over the Interior of British Columbia, dry and less stable conditions existed with daytime mixing heights over $3 \mathrm{~km}$ a.s.l. (Fig. $4 \mathrm{~b}$ ). The variations in $8 \mathrm{~h} \mathrm{O} 3$ and $24 \mathrm{~h} \mathrm{PM} 2.5$ enhancements (with uncertainty estimates) across the Pacific Northwest are listed in Table 4 and are discussed in more detail in the following sections.

\subsection{Plume chemistry at Whistler High Elevation Monitoring Site}

The Whistler Peak High Elevation Monitoring Site is situated to monitor air chemistry in the free troposphere, such as background air pollutants, and to study long-range transport events across the Pacific (Leaitch et al., 2009; Macdonald et al., 2011). On 6 July, significant increases in $1 \mathrm{~h} \mathrm{O}$,
$\mathrm{CO}$, and $\mathrm{PM}_{2.5}$ mark the onset of the smoke event at Whistler Peak (Fig. 5) and coincide with the timing of elevated aerosol layers detected by the Whistler lidar. Aerosol backscatter ratios show that the plume persisted over Whistler from 6 July 14:00 ST (WHI1) to 8 July 06:00 PST (WHI2) at an elevation of $2-3.6 \mathrm{~km}$ a.s.l. Backscatter ratios also indicate the entrainment of the aerosols deeper into the Whistler Valley as hourly observed $\mathrm{O}_{3}, \mathrm{PM}_{2.5}$, and $\mathrm{CO}$ reached peaks of $86 \mathrm{ppbv}, 24 \mu \mathrm{g} \mathrm{m}^{-3}$, and $276 \mathrm{ppbv}$, respectively. The maximum $1 \mathrm{~h} \mathrm{O}_{3}$ and $\mathrm{CO}$ values were approximately 50 and $167 \mathrm{ppbv}$ above the average July background levels as reported in Macdonald et al. (2011) for 2002-2006. $\mathrm{O}_{3}$ conditions prior to the event were consistent with July background levels.

The ratio of $\mathrm{O}_{3}$ to $\mathrm{CO}$ enhancements $\left(\Delta \mathrm{O}_{3} / \Delta \mathrm{CO}\right)$ provides some insight into the relative photochemical production of $\mathrm{O}_{3}$ in wildfire plumes (Jaffe and Wigder, 2012) and is strongly influenced by the travel time between the fire and measurement location (Mauzerall et al., 1998). For this study, 
Table 3. Summary of ambient $\mathrm{O}_{3}$ and $\mathrm{PM}_{2.5}$ conditions for stations that had severe (in bold) air quality degradation (exceeding one of the values listed in Table 2) between 6 and 11 July. Values indicated reflect the maxima of 1,8 , and $24 \mathrm{~h}$ averaging periods. Values in bracket denote historical July average daily maxima of 1 and $8 \mathrm{~h}$ average periods and the historical July average of $24 \mathrm{~h}$ running mean.

\begin{tabular}{|c|c|c|c|c|c|}
\hline \multirow[t]{2}{*}{ Station(s) } & \multirow{2}{*}{$\begin{array}{r}\text { Station(s) } \\
\text { ID }\end{array}$} & \multicolumn{2}{|c|}{$\mathrm{O}_{3}(\mathrm{ppbv})$} & \multicolumn{2}{|c|}{$\mathrm{PM}_{2.5}\left(\mu \mathrm{g} \mathrm{m}^{-3}\right)$} \\
\hline & & $8 \mathrm{~h}$ & $1 \mathrm{~h}$ & $24 \mathrm{~h}$ & $1 \mathrm{~h}$ \\
\hline \multicolumn{6}{|l|}{ Whistler } \\
\hline Whistler Peak High Elevation Site & 1 & 83 & 86 & 12 & 24 \\
\hline \multicolumn{6}{|l|}{ Lower Fraser Valley } \\
\hline Port Moody Rocky Point Park & 2 & $45(28)$ & $55(34)$ & $19(7)$ & $26(13)$ \\
\hline Chilliwack Airport & 3 & $67(35)$ & $74(41)$ & $14(6)$ & $21(12)$ \\
\hline Hope Airport ${ }^{\mathrm{a}}$ & 4 & $64.8(39)$ & $79(43)$ & $18(6)$ & $21(11)$ \\
\hline \multicolumn{6}{|l|}{ Washington State ${ }^{b}$} \\
\hline Enumclaw & 5 & 72 & 80 & - & - \\
\hline \multicolumn{6}{|l|}{ Southern Interior } \\
\hline Kelowna College & 6 & $74(40)$ & $78(44)$ & $15(5)$ & $30(13)$ \\
\hline Vernon Science Centre & 7 & $67(32)$ & $73(36)$ & $19(5)$ & $30(12)$ \\
\hline Kamloops Fire Station & 8 & $65(39)$ & $72(43)$ & $36(5)$ & $44(12)$ \\
\hline \multicolumn{6}{|l|}{ Central Interior } \\
\hline Williams Lake ${ }^{c}$ & 9 & $80(34)$ & $84(37)$ & $34(5)$ & $46(16)$ \\
\hline Quesnel $^{\mathrm{c}}$ & 10 & $76(31)$ & $92(35)$ & $31(6)$ & $57(20)$ \\
\hline Prince George ${ }^{c}$ & 11 & - & - & $31(6)$ & $49(17)$ \\
\hline \multicolumn{6}{|l|}{ Northern Interior (N. INT) } \\
\hline Burns Lake Fire Centre & 12 & - & - & $28(3)$ & $38(9)$ \\
\hline Houston Firehall & 13 & - & - & $27(3)$ & $38(9)$ \\
\hline Telkwa & 14 & - & - & $26(3)$ & $36(11)$ \\
\hline
\end{tabular}

a Air quality conditions at Hope Airport are noted here as it nearly exceeded the regional $8 \mathrm{~h}$ ozone objective. ${ }^{\mathrm{b}}$ Encompasses coastal stations in northwestern Washington State as shown in Fig. $1 .^{\mathrm{c}}$ Multiple stations in the area of interest.

the plume age is estimated to be between 7 and 10 days old based on a Siberian origin of 29 June 2012. The $\Delta \mathrm{O}_{3} / \Delta \mathrm{CO}$ ratio was estimated using observations from WHI1 to WHI2 and excluding cases where $\mathrm{CO}$ was lower than the July background (110 ppbv). The regression slope of $\mathrm{O}_{3}$ and $\mathrm{CO}$ for the event ranged from 0.15 to 0.24 with a mean value of $0.26\left(n=20, r^{2}=0.80\right)$ and is comparable to other similarly aged Siberian plumes with excess ratios of $0.22-0.36$ (6-10 days; Bertschi et al., 2004) and 0.15-0.84 (7-10 days, $n=5$; Bertschi and Jaffe, 2005).

As shown in Fig. 5d, during the smoke event (WHI1 to WHI2) the $\mathrm{PM}_{2.5}$ mass was dominated by submicron aerosol with an average $\mathrm{PM}_{1} / \mathrm{PM}_{2.5}$ ratio of 0.96 . The particle composition as determined from the ACSM (Fig. 6) during the event was on average approximately $87.6 \%$ organic mass, $3.7 \% \mathrm{NO}_{3}^{-}, 5.9 \% \mathrm{SO}_{4}^{2-}, 2.5 \% \mathrm{NH}_{4}^{+}$, and $0.3 \% \mathrm{Cl}^{-}$. $\mathrm{PM}_{1}$ mass is estimated from the ACSM, since the size distribution data indicate that most of the mass is below $0.7 \mu \mathrm{m}$; in Fig. S3, an example is shown for 9 July 2012, when the SMPS became operational again. Further, a comparison of the mass concentrations estimated from the SMPS, based on the assumptions of spherical particles and a particle mass density of $1.2 \mathrm{~g} \mathrm{~cm}^{-3}$ as a result of the dominant organic composition during that period (Fig. 6), with the ACSM for 9-31 July is illustrated in Fig. S4. The comparison is strong over the $5181 \mathrm{~h}$ averaged data: $r^{2}=0.95$; slope $=1.10$. As in the example in Fig. S3, the $\mathrm{PM}_{2.5}$ mass is estimated with the addition of the OPC data.

The evolution of PM concentrations in wildfire plumes is largely affected by the rate of SOA formation (Akagi et al., 2012). Using the regression methods described in Wigder et al. (2013), $\Delta \mathrm{PM}_{1} / \Delta \mathrm{CO}$ is estimated at 0.08 ( $\left.n=20, r^{2}=0.94\right)$ during the WHI1 to WHI2 period. This ratio is comparable to those of long-range transported plume $(>740 \mathrm{~km})$ of 0.03 and 0.06 found in Weiss-Penzias et al. (2007) and Wigder et al. (2013), respectively. Compared to the median ratios of $0.17,0.29,0.29$, and 0.19 , corresponding to distances of $<140,140-340,340-540$, and 540$740 \mathrm{~km}$ as reported by Wigder et al. (2013), the ratio found in this study is relatively low, suggesting that the net $\mathrm{PM}_{1}$ loss 

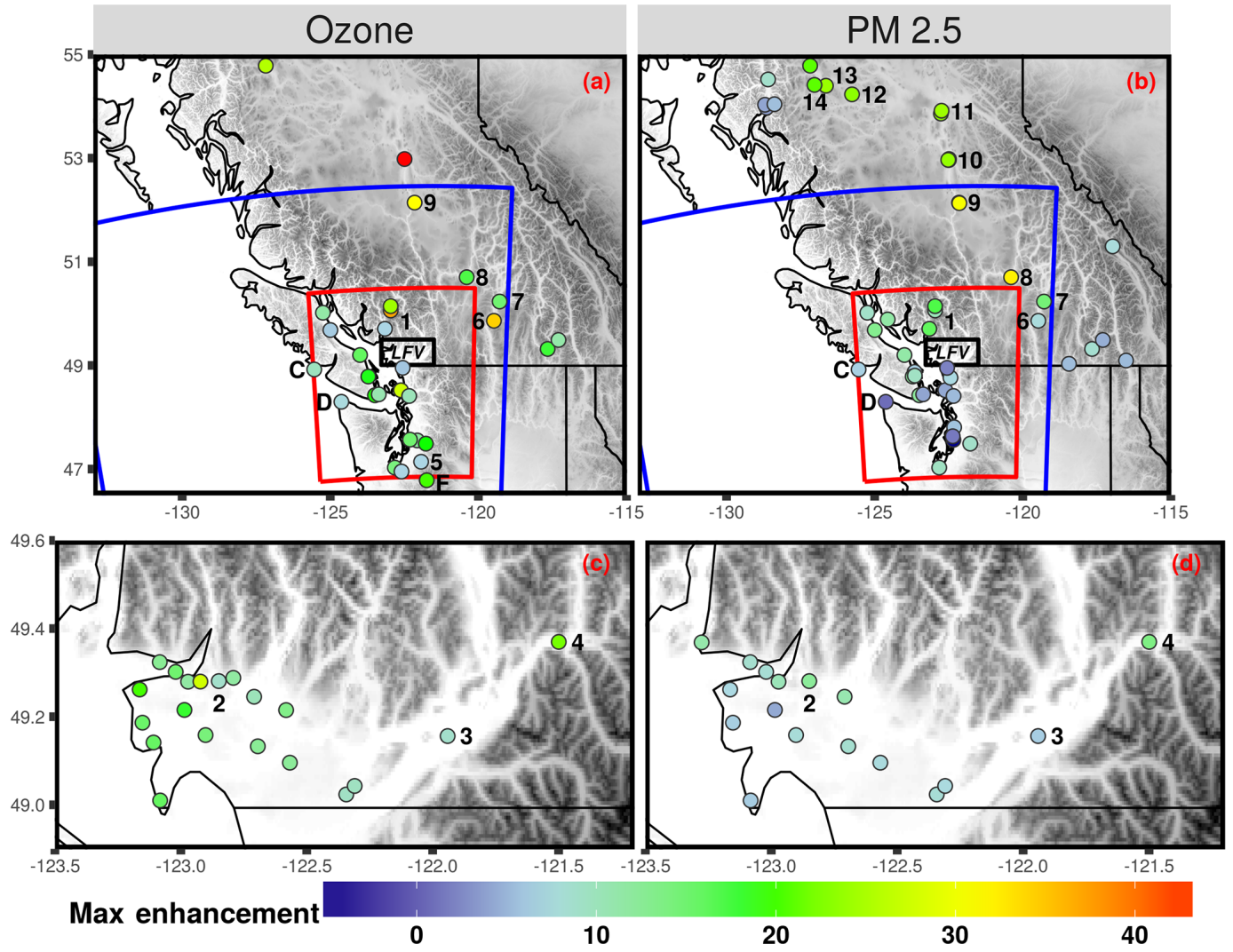

Figure 3. Overview of the maximal enhancements to $8 \mathrm{~h} \mathrm{O}_{3}$ and $24 \mathrm{~h} \mathrm{PM}_{2.5}$ estimated for the study area (a and $\mathbf{b}$, respectively) and the LFV (c and $\mathbf{d}$, respectively) based on the differences between the ambient air quality observation and the AURAMS baseline modelling for the 6-10 July 2012 smoke event. Abbreviations used in this figure are defined in Table S1 and throughout the text.
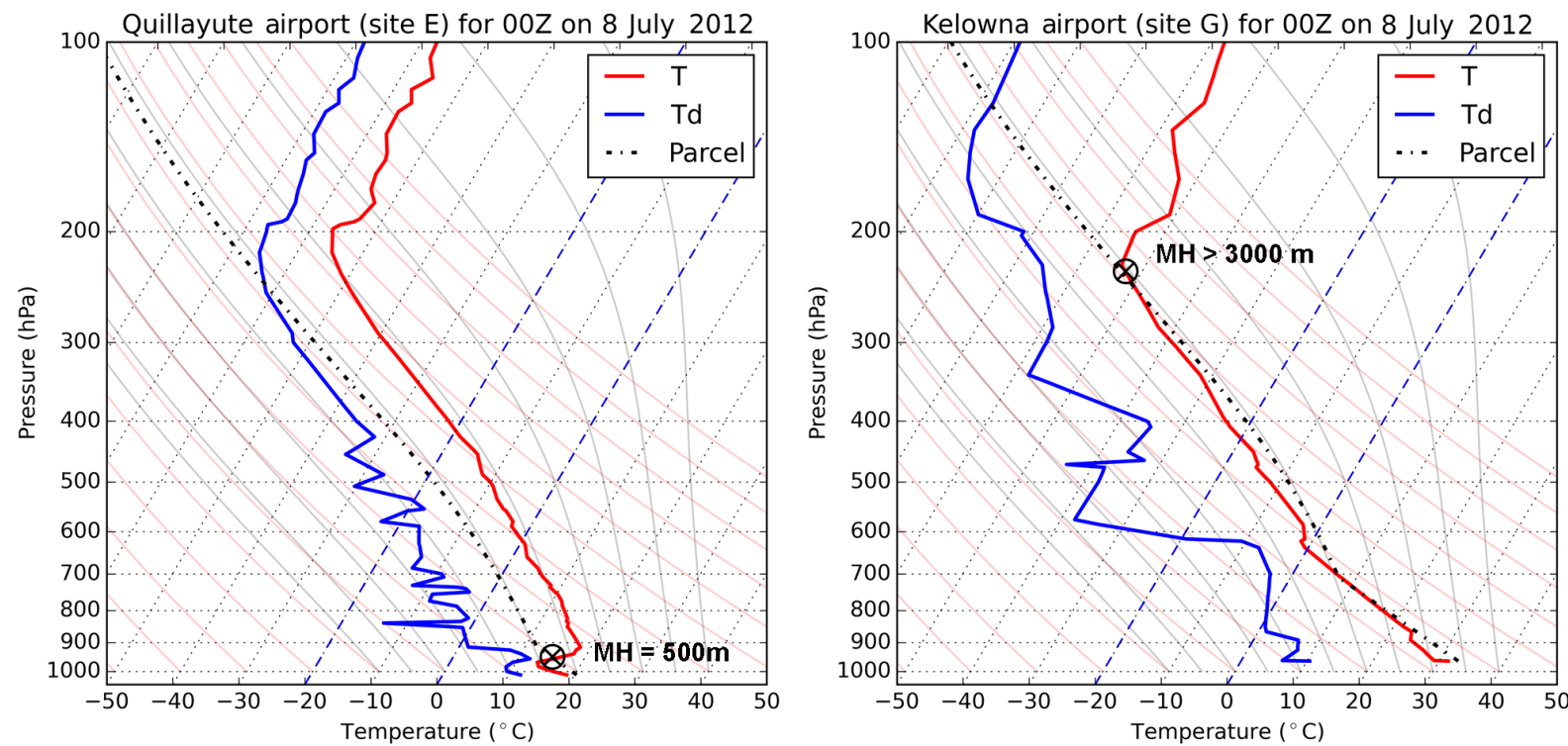

Figure 4. Skew-T atmospheric radiosondes for Quillayute (site E) and Kelowna Airport (site G) at 00Z on 8 July 2012 . The atmospheric dry bulb temperature $(T)$ and dew point temperature $(T d)$ are shown from the surface up to $100 \mathrm{mb}$. Black dashed line is a trace of a surface parcel lift to estimate the mixed layer depth at the height where it intersects the environmental dry bulb temperature. 

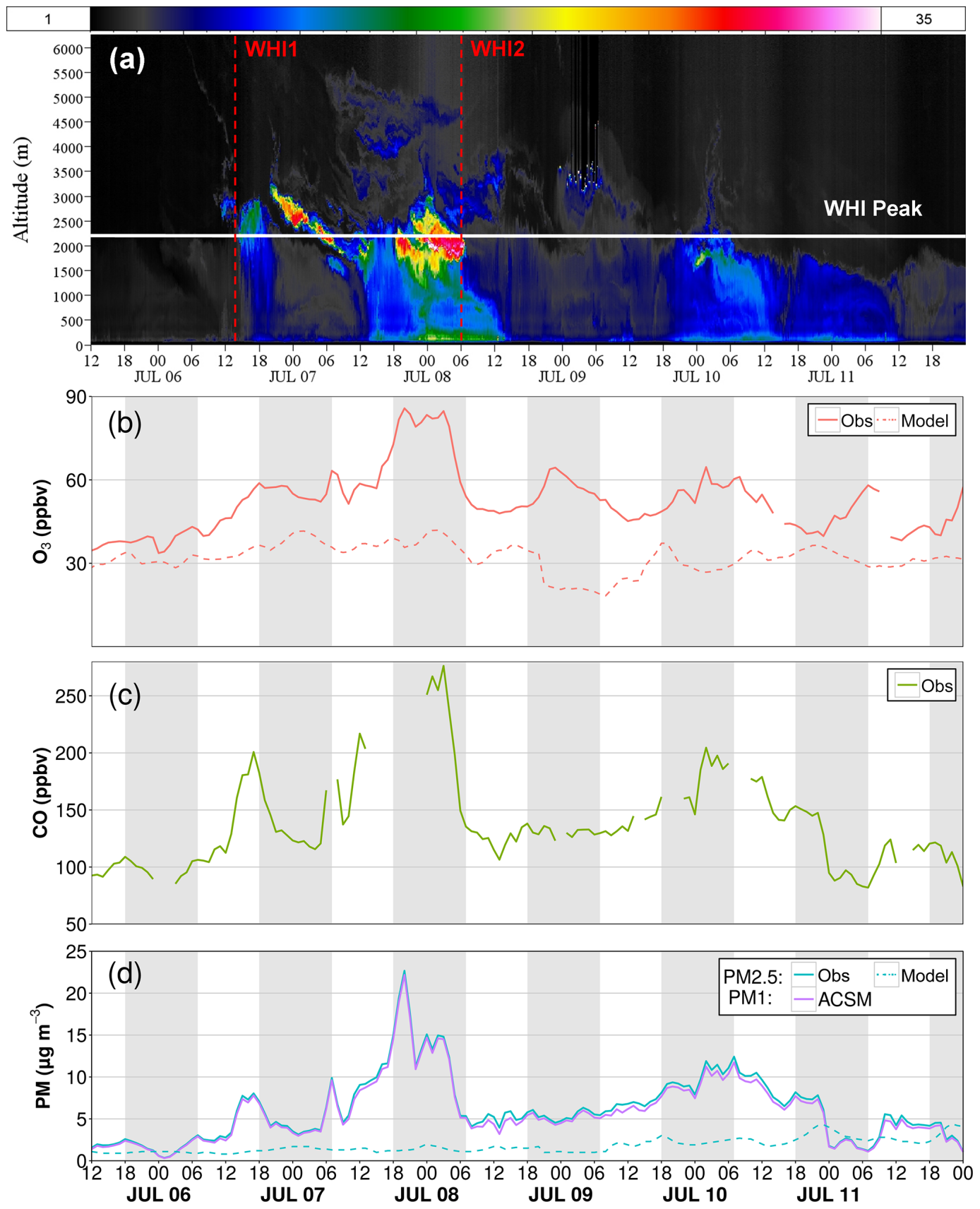

Figure 5. Whistler lidar (site A, $650 \mathrm{~m}$ a.s.1.) measured backscatter ratio of the $1064 \mathrm{~nm}$ channel to that of clear air for the July $2012 \mathrm{Siberian}$ smoke plume (a) and observed (solid) $1 \mathrm{~h} \mathrm{O} 3$ (b), $1 \mathrm{~h} \mathrm{CO}$ (c), and $1 \mathrm{~h} \mathrm{PM}_{1}$ (based on the ACSM) and PM 2.5 . (d) at Whistler Peak High Elevation station (site 1, $2182 \mathrm{~m}$ a.s.l., indicated as a horizontal white line in panel a). AURAMS baseline (dashed) $1 \mathrm{~h} \mathrm{O}_{3}$ and $1 \mathrm{~h} \mathrm{PM}_{2.5}$ are shown in panel (b) and (d), respectively. Elevated aerosol backscatter in panel (a) are noted from 6 July 14:00 PST (WHI1) to 8 July 06:00 PST (WHI2) by red dashed lines. The shaded regions indicate nighttime hours between 18:00 and 07:00 PST.

exceeds SOA formation during transport as the plume ages. A recent wildfire study (Jolleys et al., 2012) found little SOA production in aged biomass burning plumes; however, it was noted that other aircraft campaigns had found a large variability in OA enhancements.
The OC / EC ratio is also considered as its increase may indicate a contribution from SOA formation to the OC as a smoke plume ages. From the 8-day integrated $\mathrm{PM}_{1}$ quartz filter samples, separated by day and night, the value of OC / EC was 3.8 (day) and 3.4 (night) at Whistler Peak for the period 3-11 July. During the WHI1-WHI2 event, an OC / EC ratio 

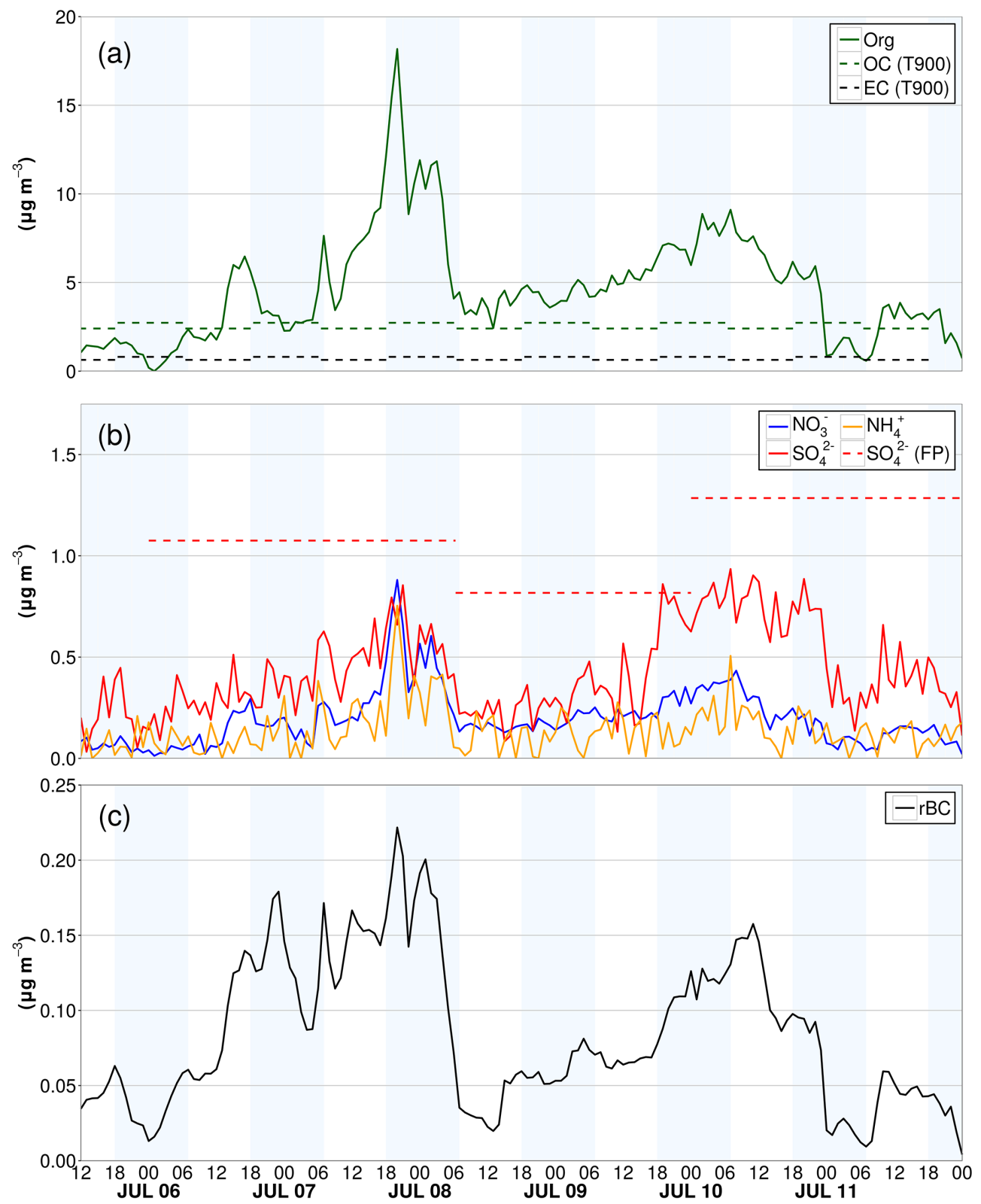

Figure 6. Aerosol chemistry measurements taken at Whistler Peak High Elevation site (site 1) between 6 and 12 July 2012 . Hourly organics $(\mathrm{Org}), \mathrm{NO}_{3}^{-}, \mathrm{NH}_{4}^{+}$, and $\mathrm{SO}_{4}^{2-}$ measured by the ACSM (a, b); EC and OC as sampled over a 8-day period (3-11 July, with day and night split) using the EnCan Total-900 thermal method (T900) (a); $\mathrm{SO}_{4}$ as a 3-day integrated sample by quartz filter pack (FP) (b); and rBC as acquired using the Single Particle Soot Photometer (SP2) (c). The shaded regions indicate nighttime hours between 18:00 and 07:00 PST.

of 3.7 was also estimated by scaling the average ACSM OM and $\mathrm{rBC}$ to the 8-day integrated $\mathrm{OC}$ and EC sample, respectively. In the week prior to 1 July 2012, a large variation in OC / EC (approximately 1.2 to 7 ) was observed in the suburb of Novosibirsk, approximately $400-800 \mathrm{~km}$ south to southwest of the main sources of the Siberian wildfire (Smolyakov et al., 2014). Due to this large variation in OC / EC close to the source as attributed to variations in burning phase and fuel types, no further inferences of SOA formation in the plume were made. The ratios of $m / z 44$ and $m / z 43$ to OM derived from the ACSM, indicate that the organic aerosol during the height of the biomass burning plume (WHI1 to WHI2) was more oxygenated than at any other time during 5-11 July (Fig. S5). If SOA production during the plume transport was insignificant, then this observation implies either a relatively high level of oxygenation near the source, heterogeneous oxidation of the OM during plume transport, 
Table 4. Maximum daily enhancement (observed-model) of daily maximum $8 \mathrm{~h}$ rolling average $\mathrm{O}_{3}$ and $24 \mathrm{~h}$ rolling average $\mathrm{PM} 2.5$ based on various air quality baselines (4 and $12 \mathrm{~km}$ AURAMS and historical values) from 6 to 11 July 2012.

\begin{tabular}{|c|c|c|c|c|c|c|c|}
\hline \multirow[b]{2}{*}{$\begin{array}{l}\text { Area of } \\
\text { interest }\end{array}$} & \multirow[b]{2}{*}{ Baseline } & \multicolumn{3}{|c|}{$\mathrm{O}_{3}$ (ppbv) } & \multicolumn{3}{|c|}{$\mathrm{PM}_{2.5}\left(\mu \mathrm{g} \mathrm{m}^{-3}\right)$} \\
\hline & & $\begin{array}{r}\text { No. of } \\
\text { sites }\end{array}$ & Enhancement & $\begin{array}{r}\text { Uncertainty } \\
\text { range }\end{array}$ & $\begin{array}{r}\text { No. of } \\
\text { sites }\end{array}$ & Enhancement & $\begin{array}{r}\text { Uncertainty } \\
\text { range }\end{array}$ \\
\hline Whistler Peak & AURAMS (4 km) & 1 & 43.7 & $(15.8,49.2)$ & 1 & 10.3 & $(7.7,10.6)$ \\
\hline $\mathrm{LFV}^{\mathrm{a}, \mathrm{b}}$ & & 20 & 9.9 & $(1.6,22.0)$ & 17 & 8.7 & $(6.0,12.8)$ \\
\hline Vancouver Island & & 6 & 13.7 & $(1.7,27.0)$ & 9 & 9.4 & $(7.1,13.1)$ \\
\hline Ucluelet & & 1 & 12.4 & $(0.1,14.9)$ & 1 & 6.6 & $(0.9,5.8)$ \\
\hline $\mathrm{US}^{\mathrm{a}, \mathrm{b}, \mathrm{c}}$ & & 10 & 10.4 & $(0,23.4)$ & 10 & 3.8 & $(4.1,12.4)$ \\
\hline Kelowna $^{a}$ & AURAMS (12 km) & 1 & 5.6 & $(5.5,19.6)$ & 1 & 7.7 & $(9.6,11.0)$ \\
\hline Vernon $^{\mathrm{a}}$ & & 1 & 14.6 & $(16.7,32.6)$ & 1 & 14.7 & $(9.8,13.1)$ \\
\hline Kamloops $^{\mathrm{a}}$ & & 1 & 18.2 & $(22.0,33.3)$ & 1 & 32.1 & $(29.2,33.1)$ \\
\hline Williams Lake & & 1 & 37.5 & $(20.3,57.0)$ & 2 & 30.3 & $(23.9,31.3)$ \\
\hline Williams Lake & Historical (6 July) & 1 & 38 & - & 2 & 31 & - \\
\hline Quesnel & & 1 & 43 & & 3 & 24 & \\
\hline Prince George & & - & - & & 2 & 23 & \\
\hline Northern Interior & & 1 & 34 & & 4 & 22 & \\
\hline
\end{tabular}

${ }^{a}$ Estimated enhancement excluding 10 and 11 July. ${ }^{\mathrm{b}} \mathrm{O}_{3}$ enhancements were based on daytime values. ${ }^{\mathrm{c}}$ Encompass northwestern coastal stations in Washington State as shown in Fig. 1.

or the loss of less oxygenated components of the OM during transport.

The overall contribution of the 6-10 July Siberian plume event to the air quality standards for $\mathrm{O}_{3}$ and $\mathrm{PM}_{2.5}$ at Whistler Peak (site 1) were estimated using AURAMS baseline modelling (also shown in Fig. 5). Generally, the model depicts relatively clean air quality conditions (approximately $30 \mathrm{ppbv}$ and $1.0 \mu \mathrm{g} \mathrm{m}^{-3}$ for $\mathrm{O}_{3}$ and $\mathrm{PM}_{2.5}$, respectively) on 5 July with an increase trend in baseline $\mathrm{O}_{3}$ (between 5 and $10 \mathrm{ppbv}$ from 5 to $8 \mathrm{July}$ ). It is estimated that the Siberian wildfires contributed an additional $44 \mathrm{ppbv}$ to the daily maximum $8 \mathrm{~h} \mathrm{O}_{3}$ and $10 \mu \mathrm{g} \mathrm{m}^{-3}$ to the $24 \mathrm{~h} \mathrm{PM}_{2.5}$ concentration (Table 4).

\subsection{Lower Fraser Valley}

The UBC lidar (site B) data indicated a plume arrival time of 12:00 PST on 6 July (LFV1, Fig. 7a) and a plume elevation of between 2 and $3.6 \mathrm{~km}$ a.s.l. over Metro Vancouver, which is similar to that found by the Whistler lidar (site A) but with generally weaker aerosol backscatter ratio readings (Fig. 7a). The plume had a shorter overall persistence over Metro Vancouver with the plume's trailing edge shifting northward by 03:00 PST on 8 July (LFV2). It appears that the conditions favourable for the transport of Siberian smoke to LFV were also conducive to $\mathrm{O}_{3}$ production (e.g. light winds, clear skies, and high temperatures). This makes the attribution of Siberian smoke impacts on local air quality slightly more challenging in the LFV than at Whistler. Figure $7 \mathrm{~b}$ and $\mathrm{c}$ depict the increasing $\mathrm{O}_{3}$ and $\mathrm{PM}_{2.5}$ across the LFV during 6-10 July with the network average $1 \mathrm{~h} \mathrm{O} \mathrm{O}_{3}$ and
$1 \mathrm{~h} \mathrm{PM}_{2.5}$ rises to $54 \mathrm{ppbv}$ and $18 \mu \mathrm{g} \mathrm{m}^{-3}$, respectively, on 8 July. Peak $\mathrm{O}_{3}$ condition of 79 ppbv observed at Hope Airport (site 4) and $\mathrm{PM}_{2.5}$ of $26 \mu \mathrm{g} \mathrm{m}^{-3}$ at Port Moody Rocky Point (site 2) arose as inland temperature reached a maximum of $31^{\circ} \mathrm{C}$ at Chilliwack (site 3) on 8 July. Inland temperatures and $\mathrm{O}_{3}$ conditions moderated subsequently on 9 July following a brief period of elevated convection in the early morning hours that affected parts of WA and LFV. High $\mathrm{O}_{3}$ concentrations were reported over the high elevation (>1000 m a.s.l.) site in North Vancouver, located close to the coast over the norther portion of the LFV, by a separate field campaign (Bart et al., 2014).

The AURAMS model was used to assess the underlying baseline air quality (Fig. $7 b$ and c) and to assess the local impacts through a site-by-site analysis of differences with LFV monitoring network data (Fig. 8a and b). For 6-8 July, the AURAMS baseline simulation without wildfire emissions captured the rise in daytime $\mathrm{O}_{3}$ on average across the LFV network (Fig. 7b) and on a site-by-site basis (Fig. 8a). In contrast, the baseline simulation was consistently lacking in nighttime $\mathrm{O}_{3}$ titration. Previous air quality studies have shown that these discrepancies do not significantly affect the rest of the baseline AQ simulation (Makar et al, 2014). As such, the estimates of $\mathrm{O}_{3}$ enhancement within the LFV are based on daytime hours only. The $1 \mathrm{~h} \mathrm{O} \mathrm{O}_{3}$ enhancements occurring on 9-10 July appear, based on the lidar data, to be about $18-27 \mathrm{~h}$ after the plume advected north of the LFV (Fig. 8a). The average enhancement of peak $8 \mathrm{~h}$ maximum $\mathrm{O}_{3}$ across the LFV was estimated to be 10 ppbv (Table 4; hourly variability shown as shaded regions in Fig. 8a). Spatial maps of $8 \mathrm{~h} \mathrm{O}$ (Fig. S6) show widespread enhancements across 

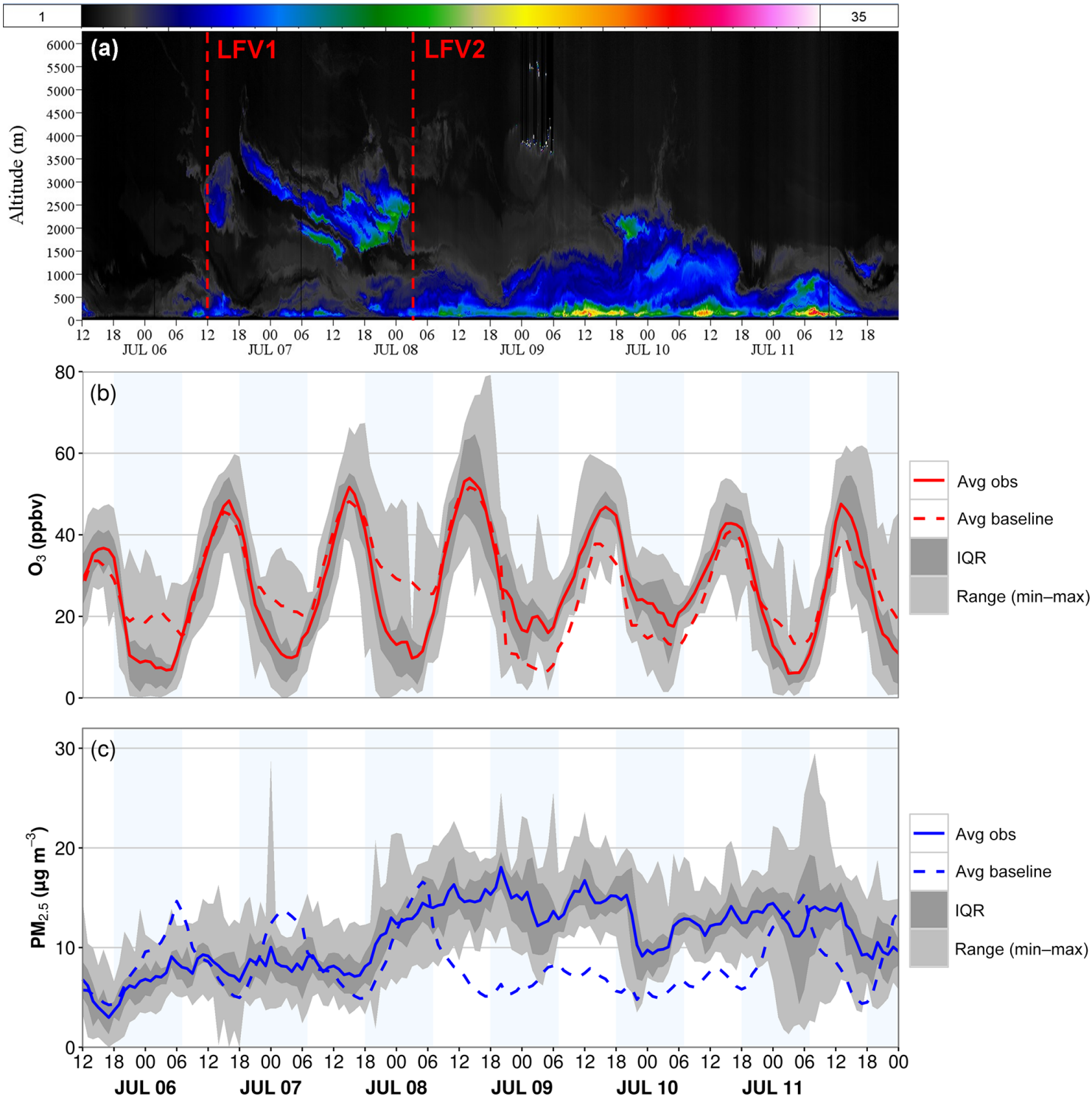

Figure 7. UBC lidar (site 2) observations and air quality conditions across the Lower Fraser Valley network between 6 and 12 July 2012. Panel (a) shows the ratio of measured backscatter of the $1064 \mathrm{~nm}$ channel to that of clear air. Panels (b) and (c) indicate the mean observed (solid) and AURAMS baseline without wildfire emissions (dashed) $1 \mathrm{~h} \mathrm{O}_{3}$ (ppbv) and $1 \mathrm{~h} \mathrm{PM}_{2.5}\left(\mu \mathrm{g} \mathrm{m}{ }^{-3}\right.$ ) for 19 and 17 sites, respectively, across the LFV air quality monitoring network. The light and dark grey shading represents the range and interquartile range, respectively, across the network at a particular hour. The vertical shaded regions indicate nighttime hours between 18:00 and 07:00 PST.

the LFV on 9 July lingered in the western portion on 10 July. The lack of $\mathrm{O}_{3}$ enhancement estimated throughout the LFV on 8 July (Figs. 8a and S6) suggests the exceedance-level $\mathrm{O}_{3}$ episode in Chilliwack (Fig. 8c) may have been due to local $\mathrm{O}_{3}$ production and not the Siberian wildfire.

The $\mathrm{PM}_{2.5}$ enhancements associated with the LRT event developed in the morning of 8 July, much earlier than with any $\mathrm{O}_{3}$ enhancements, and then persisted through $10 \mathrm{July}$. The Siberian plume is estimated to have enhanced the $24 \mathrm{~h}$ $\mathrm{PM}_{2.5}$ by a maximum of $9 \mu \mathrm{g} \mathrm{m}^{-3}$ for sites across the LFV. Spatially, the largest enhancements to $\mathrm{PM}_{2.5}$ appear to be concentrated over the northern portion of the LFV (Fig. 3 and by day in Fig. S6). This suggests that entrainment of the plume may have been facilitated by slope flows along the northern mountainous terrain, yet appears not to have reached the floor of the LFV, as evidenced by $\mathrm{O}_{3}$ data from the fixed monitoring network.

\subsection{Washington State}

In general, the air quality concentrations in WA during the episode were similar to those of the LFV. The average hourly $\mathrm{PM}_{2.5}$ across WA rose to a maximum of $\sim 15 \mu \mathrm{g} \mathrm{m}^{-3}$ on 9 

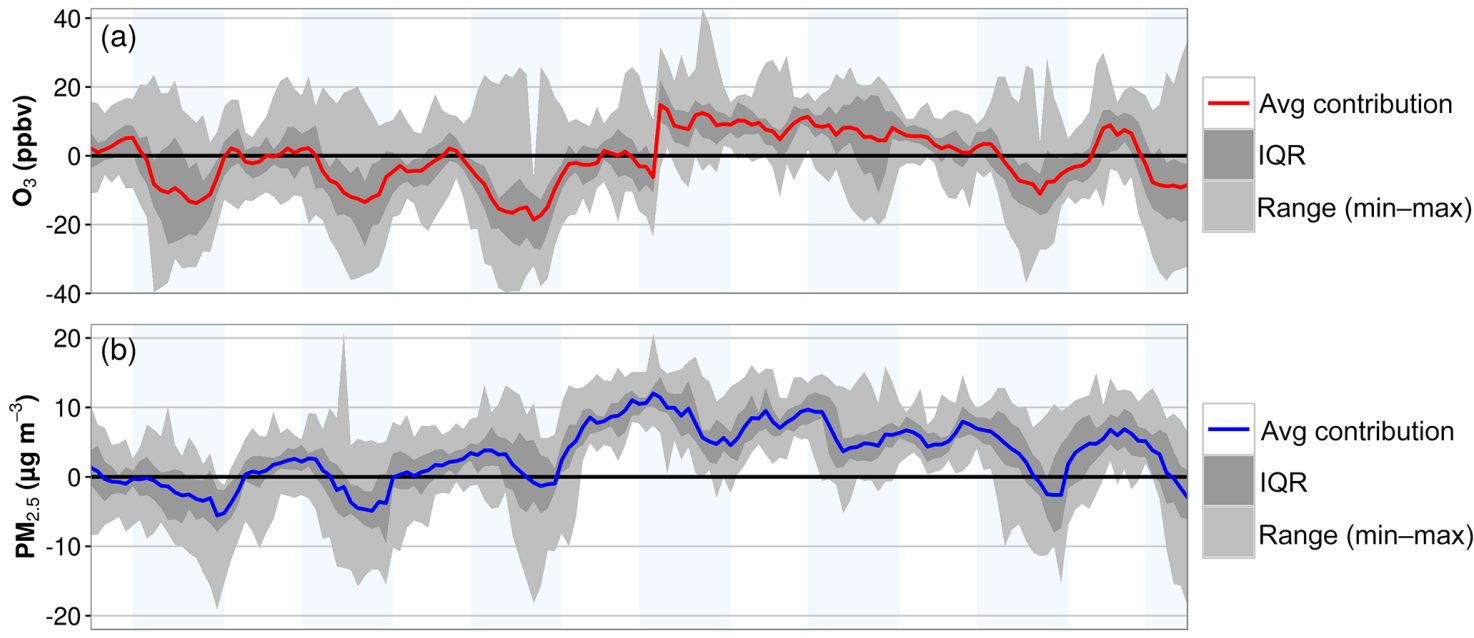

\section{- Avg contribution IQR Range (min-max)}

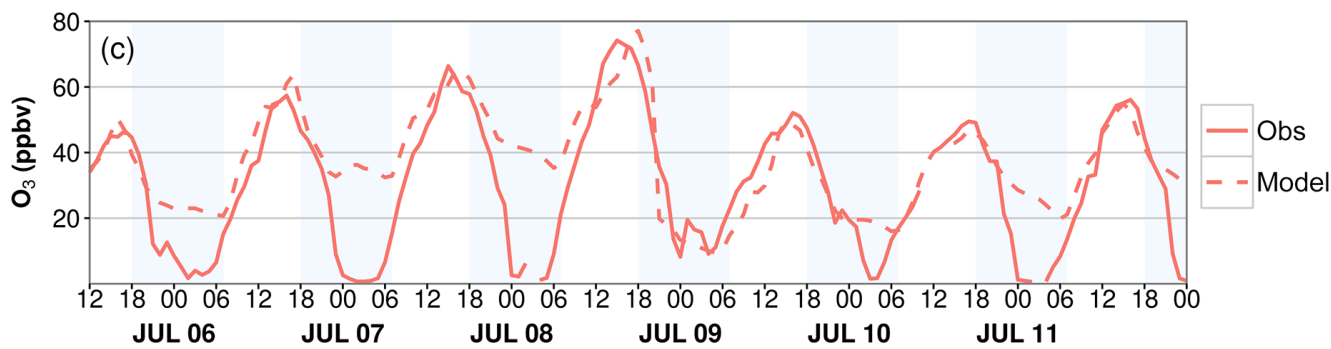

Figure 8. Contributions of the Siberian wildfire smoke plume based on the differences of observed $1 \mathrm{~h} \mathrm{O}_{3}$ (a) and $\mathrm{PM}_{2.5}$ (b) and the AURAMS baseline without wildfire emissions on a site-by-site basis for the LFV. For (a) and (b), the average contribution is labelled by the blue solid line. The light grey and dark grey shading represents the range and interquartile range of the contribution across the network at a particular hour. Panel (c) shows the AURAMS baseline and observed $\mathrm{O}_{3}$ time series for Chilliwack, BC (site 3). The light blue shaded regions indicate nighttime hours between 18:00 and 07:00 PST.
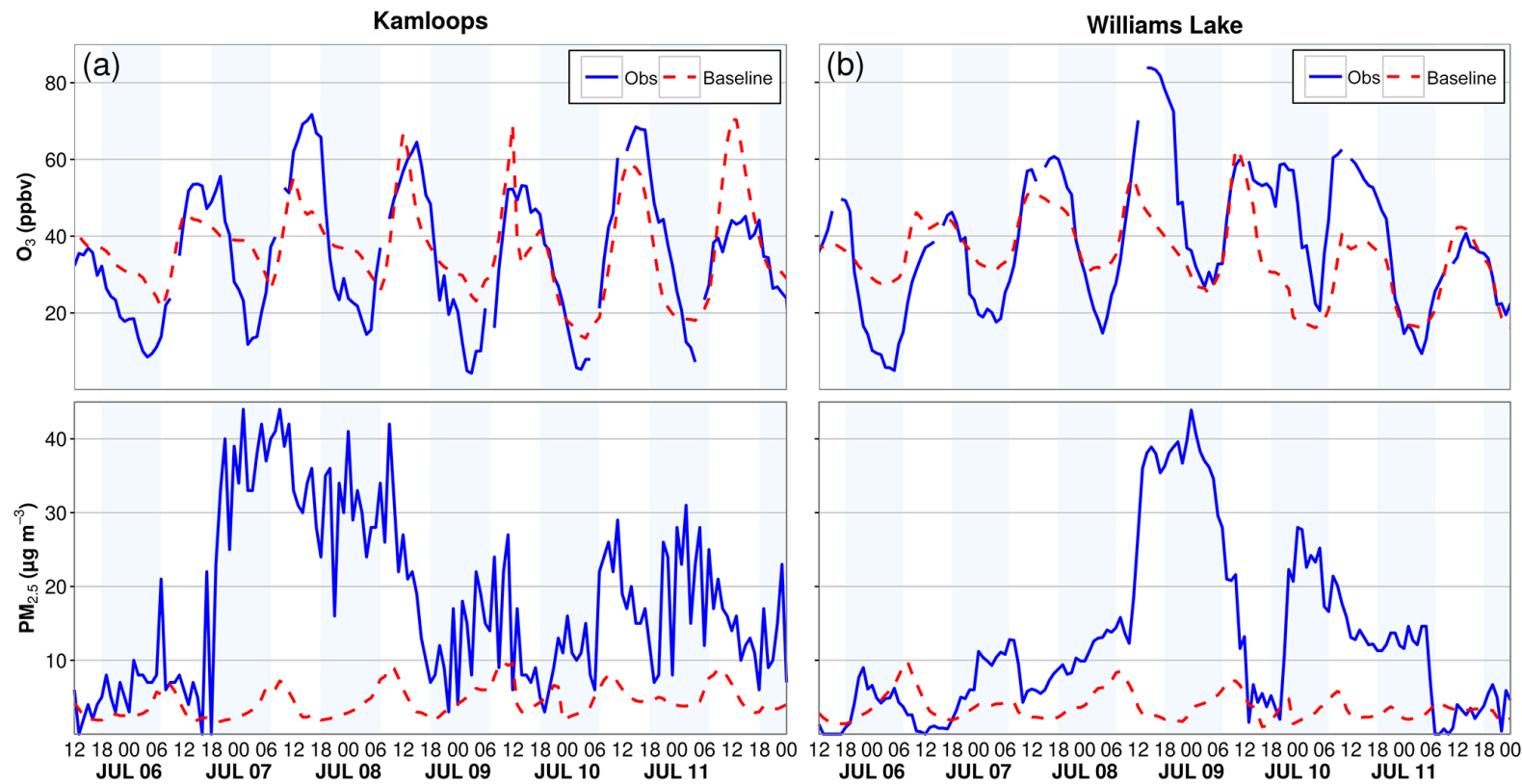

Figure 9. The hourly observed (blue) and baseline AURAMS (red, dashed) without wildfire emissions $\mathrm{O}_{3}$ (top) and $\mathrm{PM}_{2.5}$ (bottom) for Kamloops (site 8) (a) and Williams Lake (site 9) (b). The shaded regions indicate nighttime hours between 18:00 and 07:00 PST. 
July and the peak $8 \mathrm{~h} \mathrm{O} 3$ of 72 ppbv (Fig. S7) occurred at Enumclaw on 8 July. The LRT smoke enhancements in WA (Table 4) were similar to those in the LFV for $\mathrm{O}_{3}$ with a 10 ppbv increase to the $8 \mathrm{~h} \mathrm{O}_{3}$ and a weaker contribution to the $24 \mathrm{~h} \mathrm{PM}_{2.5}$ of $4 \mu \mathrm{g} \mathrm{m}^{-3}$ (Fig. 3 and by day in Fig. S6). However, the timing and geographical extent of the impacts of $\mathrm{PM}_{2.5}$ and $\mathrm{O}_{3}$ differed considerably. In particular, the impacts on $\mathrm{PM}_{2.5}$ were minimal over WA until 10 July, while $\mathrm{O}_{3}$ underwent some modest enhancement on 9 July at a limited number of monitoring locations (Fig. S7). It is likely that some of the discrepancies (between the Canadian and US portions of the LFV in the estimated plume impacts) arise from model errors stemming from different methodologies used to create the 2010 Canadian and 2008 US emissions inventories.

\subsection{The Interior of British Columbia}

The character of the Siberian plume and its impacts over the Interior of British Columbia differed considerably from the enhancements seen over the LFV and WA. The air quality for two communities (Fig. 9), Kamloops (site 8) and Williams Lake (site 9), reflects the dramatic response seen across the Interior. The arrival of the plume at these communities, 19:00 PST on 6 July for Kamloops (site 8) and 12:00 PST on 8 July for Williams Lake (site 9), resulted in a sudden shift in hourly $\mathrm{PM}_{2.5}$ and elevated $\mathrm{O}_{3}$ on the subsequent day. Based on the AURAMS modelling, it is estimated that the plume contributed an additional 18 and 38 ppbv at Kamloops (site 8) and Williams Lake (site 9), respectively, to the daily maximum $8 \mathrm{~h} \mathrm{O}_{3}$, and an additional 32 and $30 \mu \mathrm{g} \mathrm{m}^{-3}$, respectively, to the $24 \mathrm{~h} \mathrm{PM}_{2.5}$ (Table 4). The suddenness and magnitude of these impacts suggests that the plume mixed well into the boundary layer after its transition across the Coast Mountains, which also corroborates the entrainment signatures noted on the Whistler lidar that shows the plume mixed down to the base of the Whistler Valley (Fig. 5).

Unfortunately, the $12 \mathrm{~km}$ model study domain did not extend north sufficiently to provide baseline estimates of the air quality conditions to Quesnel (site 10), Prince George (site 11), and the Northern Interior (site 12 to 14 ), which also experienced conditions that exceeded national and provincial air quality standards. Instead, a baseline air quality level was inferred from the observations on 6 July and the enhancements at these sites (listed in Table 4) were found to be consistent with those experienced at Williams Lake (site 9; based on a 6 July baseline, as well as the $12 \mathrm{~km}$ domain) except for slightly weaker $24 \mathrm{~h} \mathrm{PM}_{2.5}$ enhancements of $22-24 \mu \mathrm{g} \mathrm{m}^{-3}$.

On 10 July, as the bulk of the Siberian plume shifted northeastward out of British Columbia, remnants of the plume shifted over the Southern Interior and Whistler; however, attribution of the plume's impacts was impeded due to local wildfire activity (Matthew Creek; approx. $100 \mathrm{~km}$ west of Kelowna; 155 acres). Overall, the maximal air quality enhancements due to smoke from the Siberian wildfires in the
Southern Interior was approximately $15 \mathrm{ppbv}$ and $15 \mu \mathrm{g} \mathrm{m}^{-3}$ for $8 \mathrm{~h} \mathrm{O}_{3}$ and $24 \mathrm{~h} \mathrm{PM}_{2.5}$, respectively, based on the impact analysis conducted at Vernon (site 7) for the 6-9 July period (Fig. S10).

\section{Conclusions}

The extreme 2012 Russian boreal fire season resulted in the trans-Pacific transport of a large smoke plume across the Pacific in early July which had substantial, yet varied, impacts across large parts of British Columbia and Washington State. Air quality concentrations in excess of the Canada Wide Standard (65 ppbv for $8 \mathrm{~h} \mathrm{O}_{3}$ ) and the British Columbia Air Quality Objective $\left(25 \mu \mathrm{g} \mathrm{m}^{-3}\right)$ of $24 \mathrm{~h} \mathrm{PM}_{2.5}$ were experienced on 6-10 July at several municipalities across British Columbia.

The aged smoke plume (6-10 days old), as supported from data from Whistler Peak, had a mean normalized enhancement ratio $\left(\Delta \mathrm{O}_{3} / \Delta \mathrm{CO}\right)$ of 0.26 and a $\mathrm{PM}_{1} / \mathrm{CO}$ ratio of 0.08 , consistent with other long-range transport smoke studies of similar origin. Fine organic aerosol mass (based on the ACSM measurements) accounted for the majority ( $~ 88 \%$ by mass fraction) of the 1 and $24 \mathrm{~h} \mathrm{PM}_{2.5}$ enhancements of 23 and $10 \mu \mathrm{g} \mathrm{m}^{-3}$, respectively. Analysis of OC / EC did not provide evidence for significant SOA production during transport as the plume ages. However, analysis of the ratios of $m / z 44$ and $m / z 43$ to OM derived from the ACSM, the level of oxygenation of organic material in this plume was much higher than during flanking times. If SOA formation during transport was minimal, then the relatively high level of oxygenation may have resulted from three factors: the OM near the source was relatively oxygenated; heterogeneous oxidation of the OM during plume transport; or removal of less oxygenated components of the OM during transport.

Baseline air quality modelling provided by the AURAMS model was used to delineate the scope of the LRT enhancements to air quality under varying atmospheric conditions. Generally, the largest enhancements to $8 \mathrm{~h} \mathrm{O}_{3}$ of $34-44 \mathrm{ppbv}$ and $24 \mathrm{~h} \mathrm{PM}_{2.5}$ of $10-32 \mu \mathrm{g} \mathrm{m}^{-3}$ occurred at Whistler Peak (site 1), Kamloops (site 8), and across the Central and Northern Interior of British Columbia (site 9 to 14). In contrast, lesser LRT enhancements of approximately $10 \mathrm{ppbv}$ to $8 \mathrm{~h}$ $\mathrm{O}_{3}$ and $4-9 \mu \mathrm{g} \mathrm{m}^{-3}$ to $24 \mathrm{~h} \mathrm{PM}_{2.5}$ were estimated for coastal British Columbia and Washington State. Stable atmospheric conditions along coastal area of British Columbia and Washington State likely limited the initial entrainment of the plume. The AURAMS modelling approach accounted for enhancements in anthropogenic air quality due to the smoke plume in the majority of cases with the exception of 8 July at Chilliwack (site 3) and Enumclaw (site 5), where elevated levels may have been due to other factors.

Long-range transport smoke events, such as the 2012 Siberian forest fire plume, highlight the far reaching impacts of wildfires and how air quality impacts can vary with downwind meteorology, plume age, and entrainment path- 
ways. This demonstrates the need to include wildfire emissions within chemical transport model and to derive effective parameterizations for the lofting and subsequent reactions in modelling ambient air quality conditions. Lateral boundary for chemistry used in regional air quality modelling application should be responsive to the long-range transport of pollutants. Wildfires sources pose an increasing concern as global climate change is expected to increase wildfire frequency and severity in many regions (IPCC, 2007; Gillett, 2004; Liu et al., 2013). As such, wildfire smoke is expected to contribute more to the ambient levels for $\mathrm{O}_{3}, \mathrm{PM}_{2.5}, \mathrm{CO}$, and other pollutants and can potentially increase the frequency of extended periods of degraded air quality.

\section{Data availability}

Data sources used in this paper are listed in the supplemental material (Table S3). For ECCC data not readily accessible, please contact the corresponding author (andrew.teakles@ canada.ca) for assistance.

\section{The Supplement related to this article is available online at doi:10.5194/acp-17-2593-2017-supplement.}

Author contributions. A. Teakles designed the study, developed the methodology, and prepared the manuscript with contributions from co-authors. R. So consolidated and analyzed the data and provided contributions to the methodology. J. Baik provided assistance in developing $\mathrm{R}$ code to generate figures. B. Ainslie generated the AURAMS model run. S. Hanna, A. Bertram, and L. Huang provided data and their expertise on data and instrumentation comparability. K. B. Strawbridge provided the lidar data and his expertise in interpreting these data. A. M. Macdonald and R. Leaitch provided and analyzed data collected at Whistler Peak High Elevation Site. D. Toom assisted with the ACSM data and supplementation analysis on OA oxygenation. I. McKendry provided his expertise on the LFV analysis. R. Vingarzan reviewed and provided contributions to the methodology and manuscript composition. C. Schiller reviewed the manuscript and provided her chemistry expertise to the data interpretation. R. Nissen performed the synoptic analysis. D. A. Jaffe contributed to the enhancement ratios analysis and the US analysis.

Competing interests. The authors declare that they have no conflict of interest.

Acknowledgements. We thank Jennifer Chudak and Sharon Gunter from the BC Ministry of Environment for providing the $\mathrm{O}_{3}$ and $\mathrm{PM}_{2.5}$ data for the Lower Fraser Valley and to Natalie Suzuki for air quality climatology information. We would like to acknowledge Environment and Climate Change Canada (ECCC) and the provincial, territorial, and regional governments as partners of the National Air Pollution Surveillance (NAPS) Program for the use of the time integrated ambient air quality data. We thank Eýwa Dabek-Zlotorzynska of Analysis and Air Quality Section, ECCC, for providing additional NAPS air quality $24 \mathrm{~h}$ reconstructed PM and levoglucosan dataset that were not included in this study but were helpful in our initial assessments. We acknowledge the use of Rapid Response imagery from the Land, Atmosphere Near real-time Capability for EOS (LANCE) system operated by the NASA/GSFC/Earth Science Data and Information System (ESDIS) with funding provided by NASA/HQ. Thanks to Esther Fan for her early assessment of the Siberian plume within the Lower Fraser Valley and to Paul Makar for his advice on numerical modelling. Finally, we would like to thank Ryan Mason, Jack Chen, and Paul Makar for their useful discussion regarding this paper.

Edited by: J. Surratt

Reviewed by: four anonymous referees

\section{References}

Akagi, S. K., Yokelson, R. J., Wiedinmyer, C., Alvarado, M. J., Reid, J. S., Karl, T., Crounse, J. D., and Wennberg, P. O.: Emission factors for open and domestic biomass burning for use in atmospheric models, Atmos. Chem. Phys., 11, 4039-4072, doi:10.5194/acp-11-4039-2011, 2011.

Akagi, S. K., Craven, J. S., Taylor, J. W., McMeeking, G. R., Yokelson, R. J., Burling, I. R., Urbanski, S. P., Wold, C. E., Seinfeld, J. H., Coe, H., Alvarado, M. J., and Weise, D. R.: Evolution of trace gases and particles emitted by a chaparral fire in California, Atmos. Chem. Phys., 12, 1397-1421, doi:10.5194/acp-12-13972012, 2012.

Akagi, S. K., Yokelson, R. J., Burling, I. R., Meinardi, S., Simpson, I., Blake, D. R., McMeeking, G. R., Sullivan, A., Lee, T., Kreidenweis, S., Urbanski, S., Reardon, J., Griffith, D. W. T., Johnson, T. J., and Weise, D. R.: Measurements of reactive trace gases and variable $\mathrm{O}_{3}$ formation rates in some South Carolina biomass burning plumes, Atmos. Chem. Phys., 13, 1141-1165, doi:10.5194/acp-13-1141-2013, 2013.

Bart, M., Williams, D. E., Ainslie, B., McKendry, I., Salmond, J., Grange, S. K., Alavi-Shoshtari, M., Steyn, D., and Henshaw, G. S.: High density ozone monitoring using gas sensitive semiconductor sensors in the Lower Fraser Valley, British Columbia, Environ. Sci. Technol., 48, 3970-3977, 2014.

BCMoE (British Columbia Ministry of Environment): BC air quality - network description, available at: http://www.bcairquality. ca/assessment/network-description.html (last access: 19 June 2015), 2014a.

BCMoE (British Columbia Ministry of Environment): Ambient air quality objectives. Environmental Standards Branch, available at: http://www.bcairquality.ca/reports/pdfs/aqotable.pdf (last access: 19 June 2015), 2014b.

Bein, K. J., Zhao, Y., Johnston, M. V., and Wexler, A. S.: Interactions between boreal wildfire and urban emissions, J. Geophys. Res.-Atmos., 113, D07304, doi:10.1029/2007JD008910, 2008.

Bertschi, I. T., Jaffe, D. A., Jaeglé, L., Price, H. U., and Dennison, J. B.: PHOBEA/ITCT 2002 airborne observations of transpacific transport of ozone, $\mathrm{CO}$, volatile organic compounds, and aerosols 
to the northeast pacific: Impacts of Asian anthropogenic and Siberian boreal fire emissions, J. Geophys. Res.-Atmos., 109, D23S12, doi:10.1029/2003JD004328, 2004

Bertschi, I. T. and Jaffe, D. A.: Long-range transport of ozone, carbon monoxide, and aerosols to the NE pacific troposphere during the summer of 2003: Observations of smoke plumes from Asian boreal fires, J. Geophys. Res.-Atmos., 110, D05303, doi:10.1029/2004JD005135, 2005.

Brock, C. A., Cozic, J., Bahreini, R., Froyd, K. D., Middlebrook, A. M., McComiskey, A., Brioude, J., Cooper, O. R., Stohl, A., Aikin, K. C., de Gouw, J. A., Fahey, D. W., Ferrare, R. A., Gao, R.-S., Gore, W., Holloway, J. S., Hübler, G., Jefferson, A., Lack, D. A., Lance, S., Moore, R. H., Murphy, D. M., Nenes, A., Novelli, P. C., Nowak, J. B., Ogren, J. A., Peischl, J., Pierce, R. B., Pilewskie, P., Quinn, P. K., Ryerson, T. B., Schmidt, K. S., Schwarz, J. P., Sodemann, H., Spackman, J. R., Stark, H., Thomson, D. S., Thornberry, T., Veres, P., Watts, L. A., Warneke, C., and Wollny, A. G.: Characteristics, sources, and transport of aerosols measured in spring 2008 during the aerosol, radiation, and cloud processes affecting Arctic Climate (ARCPAC) Project, Atmos. Chem. Phys., 11, 2423-2453, doi:10.5194/acp-11-24232011, 2011.

CCME (Canadian Council of Ministers of the Environment): Canada-wide standards for particulate matter and ozone - 2012 final report. Canadian Council of Ministers of the Environment, available at: http://www.ccme.ca/files/Resources/air/pm_ozone/PN_1526_

2012_CWS_for_PM_and_Ozone_Final_Report.pdf (last access: 19 June 2015), 2014.

Côté, J., Gravel, S., Methot, A., and Patoine, A.: The operational CMC-MRB global environmental multiscale (GEM) model, Part I: Design considerations and formulation, Mon. Weather Rev., 126, 1373-1395, 1998.

Cottle, P., Strawbridge, K., and McKendry, I.: Long-range transport of Siberian wildfire smoke to British Columbia: Lidar observations and air quality impacts, Atmos. Environ., 90, 71-77, doi:10.1016/j.atmosenv.2014.03.005, 2014.

Dabek-Zlotorzynska, E., Dann, T. F., Kalyani Martinelango, P., Celo, V., Brook, J. R., Mathieu, D., Ding, L., and Austin, C. C.: Canadian national air pollution surveillance (NAPS) PM2.5 speciation program: Methodology and $\mathrm{PM}_{2.5}$ chemical composition for the years 2003-2008, Atmos. Environ., 45, 673-686, 2011.

D'Amours, R., Malo, A., Flesch, T., Wilson, J., Gauthier, J.-P., and Servranckx. R.: The Canadian Meteorological Center's Atmospheric transport and dispersion modelling suite, Atmos Ocean., 53, 179-199, doi:10.1080/07055900.2014.1000260, 2015

Environment Canada: 10 years of data from the National Air Pollution Surveillance (NAPS) network - data summary from 1999 to 2008, En49-2/7-40-PDF, available at: http://publications. gc.ca/site/archivee-archived.html?url=http://publications.gc. ca/collections/collection_2014/ec/En49-2-7-40-eng.pdf (last access:15 February 2017), 2013.

Gallagher, J., McKendry, I., Cottle, P., Macdonald, A., Leaitch, R., and Strawbridge, K.: Application of lidar data to assist airmass discrimination at the whistler mountaintop observatory, J. Appl. Meteorol. Clim., 51, 1733-1739, 2012.

Gillett, N. P., Weaver, A. J., Zwiers, F. W., and Flannigan, M. D. Detecting the effect of climate change on Canadian forest fires,
Geophys. Res. Lett., 31, L18211, doi:10.1029/2004GL020876, 2004.

Gong, W., Gong, S., Dastoor, A. P., Bouchet, V. S., Makar, P. A., Moran, M. D., Pabla, B., Ménard, S., Crevier, L., Cousineau, S., and Venkatesh, S.: Cloud processing of gases and aerosols in a regional air quality model (AURAMS), Atmos. Res., 82, 248275, 2006.

Greater Vancouver Regional District (GVRD): 2005 Lower Fraser Valley air emissions inventory \& forecast and backcast. technical report, available at: http://www.metrovancouver.org/services/ air-quality/AirQualityPublications/2005_LFV_Emissions.

pdf (last access:15 February 2017), 2007.

Grimm Technologies Inc.: Grimm model 1.109 - Portable aerosol spectrometer, available at: http://www.dustmonitor.com/ Research/1109.htm (last access: 28 January 2016), 2010.

Hacker, J. P., McKendry, I. G., and Stull, R. B.: Modeled downward transport of Asian dust over Western North America during April 1998, J. Appl. Meteorol., 40, 1617-1628, 2001.

Health Canada: National ambient air quality objectives for ground-level ozone - summary science assessment document. federal - provincial working group on air quality objectives and guidelines, July 1999, available at: http://www.hc-sc.gc.ca/ewh-semt/alt_formats/hecs-sesc/pdf/ pubs/air/naaqo-onqaa/ground_level-ozone-tropospherique/ summary-sommaire/ozone-summary-sommaire-eng.pdf (last access: 19 June 2015), 1999.

Henderson, S. B. and Johnston, F. H.: Measures of forest fire smoke exposure and their associations with respiratory health outcomes, Curr. Opin. Allergy Cl., 12, 221-227, 2012.

Huang, L., Brook, J. R., Zhang, W., Li, S. M., Graham, L., Ernst, D., Chivulescu, A., and Lu, G.: Stable isotope measurements of carbon fractions (OC / EC) in airborne particulate: A new dimension for source characterization and apportionment, Atmos. Environ., 40, 2690-2705, 2006.

IPCC: Climate Change 2007: Impacts, Adaptation and Vulnerability: Contribution of Working Group II to the Fourth Assessment Report of the Intergovernmental Panel on Climate Change, edited by: Parry, M. L., Canziani, O. F., Palutikof, J. P., Van Der Linden, P. J., and Hanson, C. E., Cambridge University Press, Cambridge, UK, 976 pp., 2007

Isaev, A. S., Korovin, G. N., Bartalev, S. A., Ershov, D. V., Janetos, A., Kasischke, E. S., Shugart, H. H., French, N. H. F., Orlick, B. E., and Murphy, T. L.: Using Remote Sensing to Assess Russian Forest Fire Carbon Emissions, Clim. Change, 55, 235-249, 2002.

Jaffe, D. and Wigder, N.: Ozone production from wildfires: A critical review. Atmos. Environ., 51, 1-10, 2012.

Jaffe, D., Anderson, T., Covert, D., Trost, B., Danielson, J., Simpson, W., Blake, D., Harris, J., and Streets, D.: Observations of ozone and related species in the northeast pacific during the PHOBEA campaigns 1. ground-based observations at Cheeka Peak, J. Geophys. Res., 106, 7449-7461, 2001.

Jaffe, D., Bertschi, I., Jaeglé, L., Novelli, P., Reid, J. S., Tanimoto, H., Vingarzan, R., and Westphal, D. L. Long-range transport of Siberian biomass burning emissions and impact on surface ozone in western North America, Geophys. Res. Lett., 31, L16106, doi:10.1029/2004GL020093, 2004.

Jeong, J. I., Park, R. J., and Youn, D.: Effects of Siberian forest fires on air quality in East Asia during May 2003 and its climate implication, Atmos. Environ., 42, 8910-8922, 2008. 
Jolleys, M. D., Coe, H., McFiggans, G., Capes, G., Allan, J. D., Crosier, J., Williams, P. I., Allen, G., Bower, K. N., Jimenez, J. L., Russell, L. M., Grutter, M., and Baumgardner, D.: Characterizing the aging of biomass burning organic aerosol by use of mixing ratios: a meta-analysis of four regions, Environ. Sci. Technol., 46, 13093-13102, 2012.

Jung, J., Lyu, Y., Lee, M., Hwang, T., Lee, S., and Oh, S.: Impact of Siberian forest fires on the atmosphere over the Korean Peninsula during summer 2014, Atmos. Chem. Phys., 16, 6757-6770, doi:10.5194/acp-16-6757-2016, 2016.

Kelly, J., Makar, P. A., and Plummer, D. A.: Projections of mid-century summer air-quality for North America: effects of changes in climate and precursor emissions, Atmos. Chem. Phys., 12, 5367-5390, doi:10.5194/acp-12-5367-2012, 2012.

Lapina, K., Honrath, R. E., Owen, R. C., Martín, M. V., and Pfister, G.: Evidence of significant large-scale impacts of boreal fires on ozone levels in the midlatitude northern hemisphere free troposphere, Geophys. Res. Lett., 33, L10815, doi:10.1029/2006GL025878, 2006.

Leaitch, W. R., Macdonald, A. M., Anlauf, K. G., Liu, P. S. K., Toom-Sauntry, D., Li, S.-M., Liggio, J., Hayden, K., Wasey, M. A., Russell, L. M., Takahama, S., Liu, S., van Donkelaar, A., Duck, T., Martin, R. V., Zhang, Q., Sun, Y., McKendry, I., Shantz, N. C., and Cubison, M.: Evidence for Asian dust effects from aerosol plume measurements during INTEXB 2006 near Whistler, BC, Atmos. Chem. Phys., 9, 3523-3546, doi:10.5194/acp-9-3523-2009, 2009.

Liu, Y., Goodrick, S. L., and Stanturf, J. A.: Future U.S. wildfire potential trends projected using a dynamically downscaled climate change scenario, Forest Ecol. Manag., 294, 120-135, doi:10.1016/j.foreco.2012.06.049, 2013.

Macdonald, A. M., Anlauf, K. G., Leaitch, W. R., Chan, E., and Tarasick, D. W.: Interannual variability of ozone and carbon monoxide at the Whistler high elevation site: 2002-2006, Atmos. Chem. Phys., 11, 11431-11446, doi:10.5194/acp-1111431-2011, 2011.

Makar, P. A., Gong, W., Mooney, C., Zhang, J., Davignon, D., Samaali, M., Moran, M. D., He, H., Tarasick, D. W., Sills, D., and Chen, J.: Dynamic adjustment of climatological ozone boundary conditions for air-quality forecasts, Atmos. Chem. Phys., 10, 8997-9015, doi:10.5194/acp-10-8997-2010, 2010.

Makar, P. A., Nissen, R., Teakles, A., Zhang, J., Zheng, Q., Moran, M. D., Yau, H., and diCenzo, C.: Turbulent transport, emissions and the role of compensating errors in chemical transport models, Geosci. Model Dev., 7, 1001-1024, doi:10.5194/gmd-7-10012014, 2014.

Mauzerall, D. L., Logan, J. A., Jacob, D. J., Anderson, B. E., Blake, D. R., Bradshaw, J. D., Heikes, B., Sachse, G. W., Singh, H., and Talbot, B. Photochemistry in biomass burning plumes and implications for tropospheric ozone over the tropical South Atlantic, J. Geophys. Res., 103, 8401-8423, 1998.

McKendry, I., Christensen, E., Schiller, C., Vingarzan, R., Macdonald, A. M., and Li, Y.: Low ozone episodes at Amphitrite point marine boundary layer observatory, British Columbia, Canada, Atmos. Ocean, 52, 271-280, 2014.

McKendry, I. G., Hacker, J. P., Stull, R., Sakiyama, S., Mignacca, D., and Reid, K.: Long range transport of Asian dust to the Lower Fraser Valley, British Columbia, Canada, J. Geophys. Res., 106, 18361-18370, 2001.
McKendry, I. G., Macdonald, A. M., Leaitch, W. R., van Donkelaar, A., Zhang, Q., Duck, T., and Martin, R. V.: Trans-Pacific dust events observed at Whistler, British Columbia during INTEXB, Atmos. Chem. Phys., 8, 6297-6307, doi:10.5194/acp-8-62972008, 2008.

Metro Vancouver: Integrated air quality and greenhouse gas management plan progress report, available at: http://www.metrovancouver.org/services/air-quality/ AirQualityPublications/2014IAQGGMPProgressReport. pdf (last access: 19 June 2015), 2014.

NASA: Wildfires in Siberia (13 September 2012), available at: http://earthobservatory.nasa.gov/IOTD/view.php?id=79161 (last access: 19 June 2014), 2012.

Pfister, G. G., Emmons, L. K., Hess, P. G., Honrath, R., Lamarque, J., Martin, M. V., Owen, R. C., Avery, M. A., Browell, E. V., Holloway, J. S., Nedelec, P., Purvis, R., Ryerson, T. B., Sachse, G. W., and Schlager, H.: Ozone production from the 2004 North American boreal fires, J. Geophys. Res.-Atmos., 111, D24S07, doi:10.1029/2006JD007695, 2006.

Smolyakov, B. S., Makarov, V. I., Shinkorenko, M. P., Popova, S. A., and Bizin, M. A.: Effects of Siberian wildfires on the chemical composition and acidity of atmospheric aerosols of remote urban, rural and background territories, Environ. Pollut., 188, 8$16,2014$.

Stocks, B. J.: Forest fires in the boreal zone: climate change and carbon implications, International Forest Fire News (IFFN) 31, July-December 2004, 122-131, 2004.

Stockwell, W. and Lurmann, F.: Intercomparison of the ADOM and chemical mechanisms, Electrical Power Research Institute Topical Report EPRI 3412, 254 pp., 1989.

Strada, S., Mari, C., Filippi, J.-B., and Bosseur, F.: Wildfire and the atmosphere: Modelling the chemical and dynamic interactions at the regional scale, Atmos. Environ., 51, 234-249, 2012.

Strawbridge, K. B.: Developing a portable, autonomous aerosol backscatter lidar for network or remote operations, Atmos. Meas. Tech., 6, 801-816, doi:10.5194/amt-6-801-2013, 2013.

Sullivan, D. C., Raffuse, S. M., Pryden, D. A., Craig, K. J., Reid, S. B., Wheeler, N. J. M., Chinkin, L. R., Larkin, N. K., Solomon, R., and Strand, T.: Development and applications of systems for modeling emissions and smoke from fires: the BlueSky smoke modeling framework and SMARTFIRE, in: 17th International Emissions Inventory Conference, 2-5 June 2008, Portland, OR, USA, 2008.

Sunset Laboratory Inc.: Sunset Laboratory Inc. - Cutting Edge Carbon Aerosol Particulate Analysis Instruments, available at: http://www.sunlab.com/, last access: 21 July 2016.

Takahama, S., Schwartz, R. E., Russell, L. M., Macdonald, A. M., Sharma, S., and Leaitch, W. R.: Organic functional groups in aerosol particles from burning and non-burning forest emissions at a high-elevation mountain site, Atmos. Chem. Phys., 11, 6367-6386, doi:10.5194/acp-11-6367-2011, 2011.

US EPA (Environmental Protection Agency): National ambient air quality standards (NAAQS), available at: https://www.epa gov/criteria-air-pollutants/naaqs-table (last access: 14 February 2017), 2014.

WA ECY (Washington State Department of Ecology): Ozone monitoring procedure. 95-201G (rev. 4/08), available at: https:// fortress.wa.gov/ecy/publications/documents/95201g.pdf (last access: 19 June 2015), 2008. 
WA ECY (Washington State Department of Ecology): 2012 ambient air monitoring network report, available at: https://fortress.wa. gov/ecy/publications/publications/1202008.pdf (last access: 19 June 2015), 2012.

Weiss-Penzias, P., Jaffe, D., Swartzendruber, P., Hafner, W., Chand, D., and Prestbo, E.: Quantifying Asian and biomass burning sources of mercury using the $\mathrm{Hg}$ / CO ratio in pollution plumes observed at the Mount Bachelor Observatory, Atmos. Environ., 41, 4366-4379, 2007.

Weiss-Penzias, P., Jaffe, D. A., Jaeglé, L., and Liang, Q.: Influence of long-range-transported pollution on the annual and diurnal cycles of carbon monoxide and ozone at Cheeka Peak Observatory, J. Geophys. Res.-Atmos. 109, D23S14, doi:10.1029/2004JD004505, 2004.
Wiedinmyer, C., Akagi, S. K., Yokelson, R. J., Emmons, L. K., AlSaadi, J. A., Orlando, J. J., and Soja, A. J.: The Fire INventory from NCAR (FINN): a high resolution global model to estimate the emissions from open burning, Geosci. Model Dev., 4, 625641, doi:10.5194/gmd-4-625-2011, 2011.

Wigder, N. L., Jaffe, D. A., and Saketa, F. A.: Ozone and particulate matter enhancements from regional wildfires observed at Mount Bachelor during 2004-2011, Atmos. Environ., 75, 24-31, 2013. 